\title{
Regional order in the South Pacific and Fiji's challenge to it
}

\author{
By \\ Jack Gradwell
}

\begin{abstract}
A thesis
submitted to the Victoria University of Wellington in fulfilment of the requirements for the degree of Master of International Relations
\end{abstract}

Victoria University of Wellington 


\section{Contents}

Abstract - Page 3

Introduction - Page 4

Chapter One - Conceiving international order - Page 7

Norms and Institutions - Page 8

The role of power - Page 10

The role of legitimacy - Page 11

The prevailing world order - Page 12

Challenges to order - Page 15

Chapter Two - Regional order and the South Pacific - Page 18

The challenge of definitions - Page 18

Defining the South Pacific - Page 20

Recent Developments - A Fijian Challenge to Regional Order? - Page 20

Chapter Three - South Pacific Developments, institutions and legitimacy - Page 24

Legitimacy and the historical institutions of the South Pacific - Page 26

Hierarchical regional systems - Page 32

The South Pacific contract - Page 34

The contract's breach - how the prevailing regional order lost legitimacy - Page 36

The role of legitimacy in Fiji's challenge to order - Page 40

Chapter Four - The role of power - Page 43

The rise of the new players and their influence on the South Pacific order - Page 44

Beijing's motivations - a Chinese challenge to regional and global order? - Page 46

Chapter Five - Conclusions - the future of order in the South Pacific and Beyond Page 54

Bibliography - Page 62 


\begin{abstract}
:
Drawing from a body of leading literature on international and regional order, this thesis applies these concepts to the context of the South Pacific. Examining recent developments in the region through a framework of international order, and paying specific consideration to the regional operation of legitimacy, institutions and power dynamics, it seeks to shed light on the forces underpinning Fiji's pursuit of regionalism through alternative institutional frameworks. In this, it concludes that Suva's actions over the past decades constitute a challenge to the prevailing, Australian-New Zealand led regional order in the South Pacific, one that has occurred largely from a failure of Wellington and Canberra's policymakers to appreciate first, changing power dynamics brought about by the entry of the "new players" into the region and second, divergent views throughout the region on what constitutes legitimate state conduct. Drawing these conclusions into the broader context of global international order, this thesis unpacks the distinct meanings and motivations underpinning these developments, and in doing so explores how regional developments have mirrored global trends in the American led liberal order, offering lessons for policymakers both within the region and beyond.
\end{abstract}




\section{Introduction}

Tying together a broad array of theoretical literature on the topic of international order and challenges to it with a host of practical literature on recent regional developments in the South Pacific, this thesis drawing these developments within a framework of a challenge to international order. In doing so, it seeks to answer the question of what Fiji's pursuit of regionalism through alternative institutions represents for the future of the region as well for as the wider world.

Chapter one introduces the concept of international order - that is "the distribution of power and authority among the political actors on the global stage" and reviews a series existing literature on the topic. In doing so, this chapter makes the case that international order should be understood as a relationship between power - that is, the capacity for a state to force another to do something it would not normally do, and institutions, a "stable collection of practices and rules defining appropriate behaviour for specific groups of actors in specific situations". Building upon this conception, this chapter explores the notion of a 'challenge to international order', a situation where a dissatisfied state seeks to replace the institutions of order to ones that better reflect its interests and practices. This situation, the chapter argues, occurs most often in the context of a situation where there exists first, changing power dynamics and second, where the institutions of order (namely the most powerful states) are suffering from a declining legitimacy - that is where smaller states are no longer prepared to willingly accept them. Drawing from a variety of literature, this chapter examines how these concepts have operated throughout the globe from the Second World War onward. In doing so, it pays particular attention to developments in the post-cold war era - where conceptions of regional order have taken an increasingly dominant role, and where the United States, generally conceived as the creator and leader of the global world order, has to an extent, unilaterally shifted the institutions of order - precipitating a decline in their legitimacy amid a period where Washington's relative power to the rest of the world is declining - a status that much of the literature implies will precipitate a challenge to the global order in the near future.

Chapter two applies these idea to a local level - unpacking the concept of regions and regional order and directing them toward the context of the South Pacific. Unpicking the difficulties in defining a region, Chapter two offers a general conception of what the South Pacific region is understood to mean. Following on from there, chapter two introduces recent developments within the region - namely Fiji's pursuit of regionalism through alternative institutions. In 
doing so, it establishes an argument central to the thesis, that this pursuit represents a challenge to the existing South Pacific regional order, and not statecraft as normal.

Elaborating from the regional developments outlined in the previous chapter, Chapter three applies the central assumption to historical and present developments, exploring the scope of the regional order which Fiji seeks to challenge and why. Drawing both recent and historical regional developments into broader concepts of institutions, power dynamics and legitimacy, chapter three argues that historically, a hierarchical regional system, led by Australia and New Zealand (and at least partly to the American led world order) existed in the South Pacific. Making the case that this system's legitimacy was predicated on an implicit contract between Australia and New Zealand on the one hand and the Islands on the other, it argues that Australia and New Zealand (at least in the eyes of some of the Islands) breached this contract by acting increasingly without the consent of a large portion of the Islands. At the chapter's conclusion, it explores how this breach has influenced and engendered Fiji's challenge.

Where the previous section discussed the influence and role of legitimacy and institutions in recent regional developments, Chapter four explores the role of power. Tying in existing theoretical literature stating that challenges to order occur most often in the context of changing power dynamics, this chapter argues that the growing presence of several outside, rising global powers (namely China) in the South Pacific has changed the region's dynamics, and has consequently engendered a challenge by Fiji to the existing, Australia-New Zealand led regional order. Winding through the host of practical literature on growing Chinese involvement in the region, this chapter proceeds to explore whether these developments are indicative of something more than just a Fijian challenge to the regional order - namely a Chinese attempt to displace the existing regional powers, possibly as a part of a challenge to the global American led order.

Chapter five ties the ideas discussed in the previous four chapters together into a common framework, concluding that recent regional developments constitute an attempt by Fiji to challenge the regional order within the South Pacific by replacing its institutions. Concluding that this challenge has occurred because of a loss of legitimacy among New Zealand and Australia on the one hand, and of changing regional power dynamics brought about by the rise and entry into the region of China and others on the other, the chapter derives several lessons as to the maintenance of international order in future. Arguing that events in the scope of the American led global order have mirrored developments in the South Pacific regional order, but 
have progressed along further in the case of the latter, this chapter argues that Fiji's challenge to regional order came as a result of New Zealand and Australia's failure to first, appreciate their loss of legitimacy and the changing regional power dynamics, and second, to adapt their regional approaches to these new realities. From this, it concludes from this that unless the American led global world order adapts to meet changing realities in the way of its legitimacy and power dynamics, it will engender and encourage the same fate (a challenge to international order) that befell that in the South Pacific. 


\section{Chapter one: Conceiving international order}

International Order "the distribution of power and authority among the political actors on the global stage," 1 forms a core framework through which scholars and policymakers conceive international affairs, offering lenses through which to view diplomatic history and explain international developments.

Defined by Kissinger as "the application of the concept about the nature of just arrangements and the distribution of power," ${ }^{2}$ scholars have offered diverse understandings about what order is, how order is conceived and what its presence implies. According to Stewart Patrick, "world order" denotes a baseline level of predictability (or patterned regularity) that makes interstate relations something more than a war of all-against-all, despite the inherent structural anarchy of a system composed of independent, sovereign states."3

Hedley Bull went further, conceiving international order as a pattern of activity that sustained and served the goals of those nations and peoples a part of it. ${ }^{4}$ Accepting Thomas Hobbes' thesis that a precondition of Anarchy underpins international relations (IR), Bull argued that order can indeed exist within this framework. In stateless societies - what Bull described as anarchical communities, order can rest upon the solidarity and homogeneity within different groups - all of which might subscribe to common cultural or religious practices. Within state systems, Bull identified two distinct forms of international order. The first, which he described as an anarchical state system, was constituted upon the understanding that states would act in their own interests. The second he termed an anarchical international society. According to Bull, where groups of states become conscious of their commonalities, their shared histories, cultures and civilizational development, they could form 'anarchical societies of states'. According to Bull, these societies exist so far as nations conceive common interests, adhere to conjoined norms, and entrench them in common institutions, acting anywhere on a continuum from informal norms to entrenched international laws (more discussion on what constitutes an institution follows). ${ }^{5}$

\footnotetext{
${ }^{1}$ Falk, Richard. "World orders, old and new." Current History 98 (1999): 29.

${ }^{2}$ Kissinger, H. (2014). World Order. Penguin, p.9.

${ }^{3}$ Patrick, Stewart. "World Order: What, Exactly, are the Rules?." The Washington Quarterly 39, no. 1 (2016): p.8.

${ }^{4}$ Bull, Hedley. "The Nature of Order in World Politics." In The Anarchical Society: A Study of Order in World Politics, 3-50. 4th ed. Palgrave McMillan, 2012.

${ }^{5}$ lbid.
} 
Bull identified the source of international societies as an awakening of a common conscience. However, other scholars, including Stewart Patrick have taken a more pessimistic (though not necessarily conflicting) approach - dismissing order, and particularly formal structures of order, as but a mask established to serve the interests of great powers rather than the weak. The core implication of this thesis, is that as the creators of order, the great powers are therefore ready to violate that order or dispense with it altogether (justifying themselves in the process) where they define their interests elsewhere. ${ }^{6}$

\section{Norms and Institutions}

As the core components of international order, norms and institutions provide frameworks through which states can act with a degree of certainty. Both concepts that are problematic owing to ambiguities in their definitions, this is evidenced by Buzan's observation that "the terms 'norms', 'rules', 'values' and 'principles' are scattered throughout the array of literature, yet it is seldom clear what, if anything, differentiates them, and in many usages they seem interchangeable. All are linked by the idea that their existence should shape expectations about the behaviour of the members of a social group." 7 Acknowledging the complexities inherent in defining institutions, Buzan's contribution to the literature was to put forth a general understanding of what they entailed. In doing so, he stated: 'In common usage, 'institution' can be understood either in quite specific terms as 'an organisation or establishment founded for a specific purpose', or in more general ones as 'an established custom, law, or relationship in a society or community'... Some IR definitions of institution serve to blur the meanings of norms and institutions together, Krasner, for example, sees institutions as: 'formal or informal structures of norms and rules that are created by actors to increase their utility'." 8 Further, March and Olsen defined institutions as a "relatively stable collection of practices and rules defining appropriate behaviour for specific groups of actors in specific situations. Such practices and rules are embedded in structures of meaning and schemes of interpretation that explain and legitimise particular identities and the practices and rules associated with them". 9

Realists, such as Mearscheimer, have oft-times dismissed the capacity of institutions to effect universal positive change. Rather, they view them as self-serving structures established to

\footnotetext{
${ }^{6}$ Patrick, World Order, 10.

${ }^{7}$ Buzan, Barry . "The primary institutions of international society." In From International to World Society?, Cambridge: Cambridge University Press, 2012, 164.

8 lbid.

${ }^{9}$ Ibid., 165.
} 
preserve the status of the Great powers. ${ }^{10}$ Contrarily, supporters of institutions - that is institutionalists, contend that the value of institutions lies in their capacity to "overcome the uncertainty that undermines co-operation."11 Essentially, through extending the scope of interactions between state parties, where one might be tempted to cheat on a deal, institutions, and particularly, formalised ones (e.g. international organisations such as the United Nations) provide a framework through which they can cooperate again in future. Wary of the implications for future interactions within those institutions, this disincentives states from cheating and expands the scope of long term cooperation.

Further, institutionalists argue that institutions serve to produce or entrench norms and rules that can frame multilateral action thus greatly increasing their efficiency (putting aside definition type questions of whether institutions and norms are the same things). ${ }^{12}$ Within the post-Cold War world, institutionalist ideas have grown in salience, increasingly gaining explicit support from policymakers. For example, In 1994, U.S. Secretary of State Warren Christopher remarked that he aimed to establish "a framework of complementary, mutually reinforcing" institutions... (with which) we can promote more durable European security, through interlocking structures, each with complementary roles and strength."13 Much in alignment with the assumption inherent in Robert Keohane's assertion that "avoiding military conflict... after the Cold War depends greatly on whether the next decade is characterised by a continuous pattern of institutionalised cooperation", ${ }^{14}$ Mearsheimer claims that the existing "approach to international politics rests on the belief that institutions are a key means of promoting world peace." 15

According to Muthiah Allagappa, in recent years, international order has increasingly been organised along localised lines as successive post-cold war American presidents have asserted and delegated significant roles for formal regional institutions to manage regional conflicts and

\footnotetext{
10 Stewart, World Order, 10.

11 Slaughter, Anne-Marie. "International relations, principal theories." Max Planck encyclopedia of public international Law 129 (2011), 2.

12 Ibid.

${ }^{13}$ Mearsheimer, John J. "The false promise of international institutions." International security 19, no. 3 (1994): 5.

${ }^{14}$ Robert 0. Keohane, "The Diplomacy of Structural Change: Multilateral Institutions and State Strategies," in Helga Haftendorn and Christian Tuschhoff, eds., America and Europe in an Era of Change, Westview Press, 1993, p. 53

${ }^{15}$ Mearsheimer, The false promise of international institutions, p. 5.
} 
frame regional interactions. ${ }^{16}$ Needless to say, the consequent operation of regional institutions and order can and does significantly differ across divergent cultures and continents. While some regions are characterised by a state of significant cooperation (for example Europe and the European Union), others suffer from unpredictability and constant violence (most notably the Middle East). ${ }^{17}$ Since the end of the cold war, superpower rivalry no longer dominates the scope of regional systems, forcing greater attention on domestic regional factors. ${ }^{18}$ For example, Hurrell writes that "'Brazil's rise to regional predominance in the post-war period which should have followed from the decline of Argentina was nullified by the expansion of the United States' sphere of influence to cover the entire region. What had been a largely autonomous regional balance of power was therefore overshadowed by Brazil's position within a U.S.-dominated power system and by the constraints of the Cold War". ${ }^{19}$

\section{The role of power}

While institutions provide crucial frameworks through which order can be peacefully maintained, Stewart posits "Norms and rules are not divorced from power." The relationship between the two is as Etel Solingen writes it; that regional orders are but reflections of how ruling coalitions (that is the most powerful states) "manage their regional affairs in political, economic and strategic terms." 20 Therefore the existence of an international order is also contingent upon the application and distribution of material power - defined as the mechanism by which states can force other states to do something they would not normally do.

Within the scope of establishing and maintaining order, the role of power, according to Robert Kehone, is that it ensures that international institutions do not break down should one (often less-powerful) party determines it in their interest to not adhere to the rules, norms or frameworks they provide. ${ }^{21}$ For instance, while many states have called for the reform of the United Nations Security Council (UNSC), those that have generally lack the power of the permanent five members. As a consequence, they have generally been unable to force that

\footnotetext{
${ }^{16}$ Alagappa, Muthiah. "Regionalism and conflict management: a framework for analysis." Review of International Studies 21, no. 4 (1995): p.360.

17 Ibid.

18 Ibid.

${ }^{19}$ Hurrell, Andrew. "Brazil as a regional great power: a study in ambivalence." In Regional great powers in international politics, Palgrave Macmillan UK, 1992, 36.

${ }^{20}$ Solingen, Etel. Regional orders at century's dawn: Global and domestic influences on grand strategy. Princeton University Press, 1998, 3.

${ }^{21}$ Keohane, Robert O. "International institutions and state power." Essays in International Relations Theory, Boulder, Colo (1989).
} 
change. While happy to envision a changed institutional framework or order, without the attractive or coercive power to establish or enforce it, it cannot come into being - hence the continued dominance of the permanent members. ${ }^{22}$

\section{The role of legitimacy}

In examining the case of the UNSC, Mearsheimer's thesis that international order stems from and serves the most powerful actors/states within a system becomes more credible. Possessing greater means of coercion and influence, realists expect that the powerful players within a state system will shape order and institutions so to serve their interests best. ${ }^{23}$ However, that does not leave the smaller players completely without agency. According to Patrick, where the smaller, less powerful states are willing to accept an order, it implies at least some form of legitimacy on the part of the powerful state(s) that impose it. ${ }^{24}$ As to where legitimacy is derived, Kissinger writes that "an international order is "legitimate" if all powerful (and most small) states accept the identity and roles of the great powers (be it formally in legislation or simply informally by tacit acceptance) and embrace basic conventions and rules governing state conduct." ${ }^{25}$ Where the sources of order lack it, they also lack soft, attractive power, and so engender challenges on the part of actors dissatisfied with their positions who seek to upset that balance of power or who will seek to take advantage of it when it breaks down.

Therefore, institutions do not organically generate legitimacy in and of themselves. However, they are crucial in that when smaller states accept them, the institutions of international order (as well as the international order as a whole) are sustained on a legitimate basis. This helps to provide that level of stability, predictability and continuity necessary for any form of international order to exist, and likewise, offers smaller states some say of how international institutions are run (as the larger states generally have an interest in maintaining the legitimacy of those institutions - and in turn their leadership). In the absence of legitimate institutions, within the inherent anarchical structure of the international system, great powers are left with only coercive force to ensure the compliance of those dissatisfied states to their interests. Within these circumstances, smaller, dissatisfied states are encouraged to gain power, or utilise it should they acquire it, to challenge the institutions of the order, and force them to conform

\footnotetext{
22 Weiss, Thomas G. "The illusion of UN Security Council reform." Washington Quarterly 26, no. 4 (2003): 147161.

${ }^{23}$ Mearsheimer, The false promise of international institutions, p. 7.

24 Patrick, World Order, 10-11.

${ }^{25}$ Kissinger, Henry. A world restored: Metternich, Castlereagh, and the problems of peace, 1812-22. Pickle

Partners Publishing, 2017, 1-6.
} 
to their distinct preferences (therefore reshaping or replacing them to make the institutions of order legitimate, from their perspective).

Therefore, while it is doubtless true that a state possessing power can exert control over other parties, it can hardly be seen to create a system of international order unless it offers a system of activities that sustains its interests predictably and stably over time. In order to create this, Great Powers require institutions, which should be accepted as legitimate by the smaller states, and which must be underpinned by some arrangement of power that, according to Kissinger; "enforces restraint where rules break down, preventing one political unit from subjugating all others." ${ }^{26} \mathrm{He}$ writes further, "A consensus on the legitimacy of existing arrangements does not-now or in the past-foreclose competitions or confrontations, but it helps ensure that they will occur as adjustments within the existing order rather than as fundamental challenges to it. ${ }^{, 27}$ In essence, order should, therefore, be understood as a concept practically generated by a relationship between legitimate institutions on the one hand, and power on the other.

\section{The prevailing world order}

Where the theoretical relationship between institutions and power is applied in a practical setting to global politics, a picture emerges of the state of world order as a whole. As Patrick Stewart notes, the prevailing world order is underpinned by a large framework of norms and formal institutions (international organisations) that emerged at the close of the Second World War. ${ }^{28}$ Designed as a system to preserve peace and prevent a conflict of that magnitude from ever arising again through facilitating cooperation, it was predicated upon renewed Westphalian common norms of the sovereignty of nation states and their non-interference in each other's affairs. ${ }^{29}$ This did come, however, according to Patrick, with "two distinct suborders, one communist and the other democratic-capitalist, alongside and competing for influence within a heterogeneous third world." 30 These were formally entrenched in the charter of one of the core formal institutional component of that order, the United Nations. As the decades have progressed, this series of multilateral formal institutional frameworks has rapidly expanded. According to Stewart, Earth has witnessed the "dramatic proliferation of treaties, organisations, and other frameworks covering new spheres of global life, purporting to regulate

\footnotetext{
${ }^{26}$ Kissinger, World Order, 13.

27 Ibid.

${ }^{28}$ Patrick, World Order, 8.

29 Ibid.

${ }^{30}$ Ibid,. 9.
} 
everything from chemical weapons possession to pandemic response to civil aviation. This latticework of institutional arrangements has facilitated unprecedented cooperation in addressing challenges which transcend national borders. Thanks to this institutional proliferation, there is a measure of "governance," or purposive order, in world politics." ${ }^{31}$ Other such norms Patrick has identified as emblematic of the prevailing global order include those of the non-proliferation of weapons of mass destruction, combatting climate change and terrorism. Further, he also notes the importance to the prevailing world order of democracy promotion, and maintaining an open, liberalised world economy - norms that are entrenched in formal institutional structures such as the International Monetary Fund, World Trade Organisation and World Bank. ${ }^{32}$

At the Second World War's close, the power dynamics that facilitated the creation of these institutions and guaranteed their continued existence were based largely upon a balance of power between the two superpowers in the international system - The Soviet Union and the United States. While as Ronnie writes, "The meaning of the term... is ambiguous and a search for a definition is normally in vain... clearly shown by Wight's nine definitions," 33 its most general conception reflects a system in which states balance together to maintain the rules of order and prevent one state from dominating all others. ${ }^{34}$ By existing in a state of power equilibrium, this state could prevent individual actors (the United States or the Soviet Union) from unilaterally abandoning the institutional framework that governed the order.

However, as Kissinger writes (and Walt, ${ }^{35}$ Schweller and Pu concur), ${ }^{36}$ "Balance of power systems only emerge rarely in history" 37 and at the Soviet Union's collapse, the power dynamics underpinning the institutions of the prevailing world order in their current form diminished. In one of the most famous scholarly works of the era, Charles Krauthammer wrote in the Foreign Affairs magazine that the world was experiencing a "unipolar moment" in which

\footnotetext{
31 Ibid.

32 lbid,. 14.

33 Hjorth, Ronnie. "Hedley Bull's Paradox of the Balance of Power: A Philosophical Inquiry." Review of International Studies, vol. 33, no. 4, 2007, pp. 597-613., www.jstor.org/stable/20097962.

${ }^{34}$ Kissinger, World Order, 13.

${ }^{35}$ Walt, Stephen M. "Keeping the World Off Balance: Self Restraint and US Foreign Policy." (2000), 134.

${ }^{36}$ Schweller, Randall L., and Xiaoyu Pu. "After unipolarity: China's visions of international order in an era of US decline." International Security 36, no. 1 (2011): 41-72.

${ }^{37}$ Kissinger, Henry. Diplomacy. Simon and Schuster, 1994, 21.
} 
the United States, thanks to its overwhelming power, had an unparalleled opportunity to direct and shape the face of the global order. ${ }^{38}$

Emerging as what John Ikenberry termed a "Liberal Leviathan" in the absence of a balance of power, the changed power dynamics brought about by the fall of the Iron Curtain were definitively altered. Faced with new challenges in the preponderance of new security threats within the scope of intrastate and civil conflicts as well as terrorism, the United States adjusted its strategies accordingly. ${ }^{39}$ Washington's subsequent, often unilateral drive to establish changed global institutions (or norms) illustrates the relationship between institutions and power within the scope of international order and further adds salience to Mearscheimer's theory that the former does little to constrain the latter truly. Rather, the latter (power) reshaped the former (institutions).

Pursuing an intensified strategy of spreading its economic frameworks into territories Washington was once prevented from doing so owing to Soviet power, the United States concurrently weakened several existing institutions emblematic of the world order established at the close of the Second World War. Driven much by a desire to not repeat the mistakes of 1939-45, the post-war environment gave rise to a renewed emphasis on non-interference and sovereignty. However, at the Berlin Wall's fall, the the United States' newfound paramountcy left it able to pursue its interests more aggressively, consequently establishing and emphasising new norms of "responsibility to protect" and "contingent sovereignty" in order to facilitate it at the expense of prior conceptions of the infalliability of national sovereignty. These "new norms" were exercised in Bosnia, Kosovo and Libya largely without the approval of the United Nations Security Council - realities largely unthinkable in the Cold War era with its balance of power. ${ }^{40}$

While these developments showcase the relationship between power and institutions, and the capacity for the Great Powers to leverage their superiority to unilaterally effect institutional change, and thus change an order at will, they have not been without their consequences. According to Ikenberry, these developments have undermined the prevailing world order's legitimacy (and ignited a "crisis of authority") that may lead to a breakdown in the prevailing

\footnotetext{
38 Krauthammer, Charles. "The unipolar moment." Foreign affairs 70, no. 1 (1990): 23-33.

${ }^{39}$ Ikenberry, G. John. Liberal Leviathan: The origins, crisis, and transformation of the American world order. Princeton University Press, 2012.

${ }^{40}$ Patrick, World Order, 13.
} 
order as rising powers determine it in their interests to challenge it. ${ }^{41}$ Simply, should global power dynamics shift, it is likely that the rising powers may determine it better to challenge through force the institutions of the prevailing global order to change rather than work within them.

\section{Challenges to order}

While for now, the United States is still undoubtedly the most powerful player in the global system, changing power dynamics, brought about by the growing influence of new players, combined with Ikenberry's "crisis of authority" may foreshadow a challenge to the global order.

As Patrick Stewart writes, challenges to order occur when "dissatisfied states pursue alternative principles of order... Such challenges are most likely during rapid power transitions, as emerging powers seek to alter or replace regnant rules to conform to their own distinctive preferences," 42 Kissinger concurs, stating that challenges occur where "established powers prove unable to adapt the system's equilibrium to incorporate its (the challenger's) rise." ${ }^{43}$ As to how they occur, he asserts that while "the essence of such upheavals is that they are underpinned by force, their overriding thrust is psychological. Those under assault are challenged to defend. The basic assumptions of their way of life, their moral right to exist and to act in a manner that, until the challenge, has been treated as beyond question", ${ }^{44}$ where "order is submerged, (it is not from) military defeat or an imbalance in resources, but from a failure to understand the nature and scope of the challenge arrayed against it." ${ }^{45}$

Of the modern world, Stewart observed a rapidly shifting global power dynamic, he writes,

"Never before have we seen the simultaneous rise of multiple regional (and potentially even global) powers-led by China, of course, but also including India, Brazil, andthough smaller in economic size and political clout-South Korea, Turkey, Mexico, Indonesia, and South Africa. In 1990, when the Cold War was ending, the OECD advanced market democracies accounted for 62 percent of global GDP. Today, that figure is only 47 percent, despite the OECD's addition of a dozen new members

\footnotetext{
${ }^{41}$ Ikenberry, G. John. "Illusions of empire: defining the new American order." (2004): 144-154.

42 Patrick, World Order, 10.

${ }^{43}$ Kissinger, World Order, 366-367.

44 Ibid.

45 Ibid.
} 
including South Korea and Mexico. Most emerging players are at least mildly revisionist. The question is whether their demands can be accommodated with modest adjustments to voting weight and shares within existing institutions, as well as tweaking of rules, or whether their challenge is more fundamental." ${ }^{46}$

Some scholars, as well as the Chinese government, have repeatedly expressed their view that the rising powers' emergence on the world stage will occur in a way so that it is peaceful. They argue that as the power of the new players expands and global dynamics subsequently shift, the global institutional framework will adapt to meet their rise. Offered a greater voice and say within the existing frameworks of formal institutions, including the capacity to shape global norms, in this view, the global order will evolve to meet the rise of the new players, rather than engender challenges on their part. ${ }^{47}$

Others, however, including Patrick, have presented a far more pessimistic future. He states that while the rising powers have demanded a greater role in the existing formal institutional framework that composes the existing world order, entrenched interests continue to permeate them, resisting calls for change (The refusal of the P5 to extend permanent membership on the UN Security Council being a prime example). ${ }^{48}$ In this view, the combination of the perceptions that the institutions emblematic of the existing order are illegitimate and intractable, combined with changing power dynamics, will pressure a future challenge to global order as the new powers pursue alternative institutions to advance their interests.

Since the turn of the $21^{\text {st }}$ century, the globe has experienced and continues to experience a power transition brought on by the rapid development of second and third world economies. This transition has led to a decline in the first world (the creators of the modern institutions of international order) relative power in comparison to the rest of the world. Consequently, those rising powers, (led by the potential superpowers of the BRICS economies - Brazil, Russia, India, China and to a much lesser extent South Africa), not traditional defenders of either the liberal world order nor the democratic principles it has espoused in the post-Cold War Era, have increasingly demanded a greater say in the institutions of international order. This has

\footnotetext{
${ }^{46}$ Patrick, World Order, 20.

${ }^{47}$ Bijian, Zheng. "China's" peaceful rise" to great-power status." Foreign Affairs (2005): 18-24.

48 Patrick, World Order, 21.
} 
spurned increased questions and intense academic discussion as to whether a challenge to global order and the subsequent upheavals it could bring with it will follow. ${ }^{49}$

${ }^{49}$ Weiss, Thomas G. "Rising Powers, Global Governance, and the United Nations." Rising Powers Quarterly 1, no. 2 (2016): 7-19. 


\section{Chapter two - Regional order and the South Pacific}

Over the past two decades, developments in the South Pacific have offered a case study illustrating many of the previous chapters' theories and principles of international order in practice. Occurring within a limited, regional level context - regional developments over the past decade have been characterised by a marked struggle between Fiji on the one hand, and New Zealand and Australia on the other, over which regional institutions will form the core framework through which South Pacific states conduct regionalism and approach regional affairs. In examining this struggle and the dynamics that underpin it, one illuminates the relationships between power dynamics, institutions and legitimacy that compose regional order. Consequent to developments both local to the region and within the global international system, their impacts could foreshadow broader trends as changing power dynamics drive rising players to challenge the authority of the prevailing international order.

\section{The challenge of definitions}

Subordinate to the conception of global international order, 'regional order' is defined at its simplest "as the application of the same concepts of international order toward a given region or geographic area." ${ }^{50}$ The reason for its existence is straightforward - with the difficulty of building consensus and agreement upon institutions across states of such divergent sizes, cultures, geographies and histories, Kissinger reasons, 'The smaller the geographic area to which it applies and the more coherent the cultural convictions within it, the easier it is to distill a workable consensus. ${ }^{51}$ Consequently, states oft-times simultaneously pursue deepened institutions of order at a regional level. Since the close of the Cold War, the need for the United States to engage in anti-Soviet balancing throughout the world has diminished. According to Alagappa, where previously "the dynamics of the superpower conflict permeated and in many cases subsumed the local dynamics of conflicts", ${ }^{52}$ in the post cold-war period, greater authority and attention has been placed on "regional and sub-regional contexts, quite independent of a global dynamic or developments in other regions". ${ }^{53}$

There is no struggle to find examples of regional institutions and distributions of power (evident in the European Union, the African Union, and NATO to name a few examples). However, a widely agreed upon definition of what exactly constitutes a "region" has proved

\footnotetext{
${ }^{50}$ Kissinger, World Order, 13.

51 lbid.

${ }^{52}$ Alagappa, Regionalism and conflict management, 359.

53 Ibid.
} 
elusive - fogging the quest for understanding both its meaning and implications. Consequently, within the literature on the topic, scholars have instead tended to rely on the different and diverse contributions of a plethora of different academics. For example, Joseph Nye defined a region "as a limited number of states linked by a geographical relationship and by a degree of mutual interdependence," and (international) regionalism as "the formation of interstate associations or groupings on the basis of regions." 54 Cantoiri and Speigel noted that Nye's definition had not proven universal, stating, "All subordinate systems (regions) are delineated, at least in part by reference to geographical considerations, but social, economic, political, and organisational factors are also relevant. Consequently, members of subordinate systems (regions) are proximate, but they need not be contiguous." 55 In essence, regional order is conceived in the existing literature as encapsulating similar concepts of international order, but delineated by a series of local factors and often subordinate to the overriding global order. These local factors offer regions an environment by which facilitates a greater consensus among their constituent states, enabling regional systems to overcome some of the limitations of global order.

Concurrent to the United States' increasingly delegating authority for maintaining order to a regional level in the post-Cold-War world (a consequence of the lack of a need to focus on countering the influence of a rival superpower in the vacuum of the Soviet Union's collapse), studies of the phenomena of 'regionalism' have garnered greater attention from the 1990s onward. ${ }^{56}$ As Hurrell writes, "The core of the theory of regionalism focuses on the impact of rising levels of regional social and economic exchange and the links between economic integration, institutions and identity... Although intraregional constellations of power, interest and identity remain fundamental, the relationship between the one world of the international system and the many worlds of different regionalisms cannot be neglected. All regionalist arrangements have to be understood in relation to systemic or 'outside-in' factors."

Generally composed of what Bull described as a "society of states" bound by a consciousness of a shared history, geography, culture or development, regional orders can be seen to be shaped

\footnotetext{
${ }^{54}$ Nye, Joseph S., ed. International regionalism: readings. Little, Brown, 1968, 7.

${ }^{55}$ Cantori, Louis J., and Steven L. Spiegel. "The international relations of regions." Polity 2, no. 4 (1970), 400.

${ }^{56}$ Hurrell, Andrew. "Brazil as a regional great power: a study in ambivalence." In Regional great powers in international politics, Palgrave Macmillan UK, 1992, 36.

${ }^{57}$ Hurrell, Andrew. "One world? Many worlds? The place of regions in the study of international society." International Affairs 83, no. 1 (2007): 130.
} 
by a combination of both local developments and the global order around them. ${ }^{58}$ Just as institutions, legitimacy, norms, rules and power permeate order on a global scale, similar concepts form the basis of order on a regional scale. ${ }^{59}$ Deeply entwined with global order, regional orders are distinct by their specific, localised power dynamics, norms and institutions unique to a given area.

\section{Defining the South Pacific}

While limited literature exists upon the broader idea on the pervasiveness of regional order throughout the South Pacific, substantial scholarship exists upon the individual operation of regional institutions, power dynamics and (to a lesser extent) legitimacy (the extent to which weaker states are willing to accept the institutions and roles of the powerful) - that is, the central components that constitute an international order. Through exploring these, an image emerges of what passes for regional order in the South Pacific, and what various academics imply about its operation.

While specific definitions can be arbitrary, the concept of a 'South Pacific region' can be derived from how those foreign policy actors and academics conceive it. Where they refer to the South Pacific region, they imply those Islands of Australia, Melanesia, Micronesia and Polynesia south of the equator. Together, all share and are bound in international institutions and cultures largely separate from those of Asia. As Herr and Bergin write of both the geography and makeup of the region, "The Pacific Islands lie in the midst of the world's largest ocean but include some of the world's smallest countries. Indeed, the number of microstatesstates with resident populations of fewer than half a million-is one of the region's key identifying geopolitical characteristics. There's no greater concentration of microstates on the planet." 60

\section{Recent Developments - A Fijian Challenge to international order}

In the past decade, international diplomacy within the South Pacific has experienced significant confrontation. Having taken power in a 2006 coup (and struck with sanctions as a

\footnotetext{
${ }^{58}$ Ayoob, Mohammed. "From regional system to regional society: Exploring key variables in the construction of regional order." Australian Journal of International Affairs 53, no. 3 (1999), 248.

59 lbid.

${ }^{60}$ Herr, Richard Allen, and Bergin, Anthony. "Our near abroad, Australia and Pacific Islands regionalism." (2011), 8.
} 
consequence), ${ }^{61}$ Fiji’s leader, Prime Minister Voreque 'Frank' Bainimarama has signalled his intent to drive both the country and the region as a whole, with a new direction. Pressured by way of sanctions from New Zealand and Australia to hold elections; these were the apparent trigger of the shift. ${ }^{62}$ However, while sanctions have now been lifted (and elections held), these developments have shown no sign of abating, gaining a momentum of their own. ${ }^{63}$ Speaking to the $71^{\text {st }}$ session of the United Nations in 2016, Bainimarama explicitly outlined:

"We intend, in future, to choose our friends in a more discerning manner, and to align ourselves more closely with those countries that share our underlying values and principles... These include ... shared values such as mutual respect, respect for sovereignty and territorial integrity, the resolving of disputes by peaceful means and non-interference in each other's internal affairs." ${ }^{64}$

Put into practical terms, Fiji has from around 2006 onward, pursued seemingly divergent goals through "alternative regional frameworks" and institutions, ${ }^{65}$ advancing its interests through "sub-regional blocs" absent of Wellington and Canberra. ${ }^{66}$ Tarte writes,

"Institutional developments in Pacific Island regionalism have been dramatic ... at the United Nations (UN), Pacific Island states achieved an historic victory in the renaming of the regional bloc to which they belong, now the Asia-Pacific Small Islands Developing States grouping, and have caucused as the Pacific Small Islands Developing States (PSIDS) group on issues of sustainable development and climate change, rather than as the Pacific Islands Forum (PIF) group. Long regarded as the region's peak political body, with Australia and New Zealand as members, the PIF has in recent years been shaken by the absence of its host country Fiji (following its

\footnotetext{
61 Powles, A., and J. Souza-Santos. "Principled Engagement: Re-building Defence Ties with Fiji." Lowy Institute Analyses Paper 21 (2016).

62 Ibid.

63 Ibid.

${ }^{64}$ Bainimarama, Voreque. "Hon Bainimarama address to the UNGA." Address, 71st Session of the United Nations General Assembly, New York, September 21, 2016. Accessed June 10, 2017. http://www.fiji.gov.fj/Media-Center/Speeches/HON-PM-BAINIMARAMA--ADDRESS-TO-THE-71ST-SESSIONOF.aspx.

65 Tarte, Sandra. "Regionalism and changing regional order in the Pacific Islands." Asia \& the Pacific Policy Studies 1, no. 2 (2014), 315.

${ }^{66}$ Herr and Bergin, Our Near Abroad, 53.
} 
suspension in 2009 for failing to hold elections), and by reviews in 2012 and 2013 that

highlighted the need for a major overhaul of the Forum, if it is to retain its relevance". ${ }^{67}$

While Fiji's measures to resist sanctions would generally be considered normal statecraft, the continued prosecution of the same policies in their absence implies at more substantial motivations. Sandra Tarte for example has argued that these developments "constitute a deeper transformation, not just of the regional architecture, but of the regional order itself." ${ }^{68}$ Richard Herr and Antony Bergin concur, referring to the growth of a "rising sub-regionalism" undermining the "coherence and robustness of the regional system." ${ }^{69}$ Further, Nic Meclellan has written of how the long-held influence of Australia in the Pacific Islands Forum has been eroded as Bainimarama has taken a leading role in regional realignment. ${ }^{70}$

A number of explanations have been put forth to explain Fiji's end game. In 2012, Brij Lal noted that in the aftermath of the 2012 coup, Fiji's status as regional leader was significantly diminished. ${ }^{71}$ From this, he made the suggestion that the PIDF was a short-lived thorn in the side of the PIF, acknowledging in this case that its successes stemmed from a disapproval of New Zealand and Australia's role. Overall, his conclusion that "Perhaps all these new initiatives will be allowed quietly to relapse once Fiji returns to parliamentary democracy, and once no benefits are seen to derive from them"72 implied that Suva's strategy did not represent a substantial challenge to the existing regional institutions - but rather, limited statecraft in order to limit the effects of sanctions imposed by New Zealand and Australia and the suspension from the PIF. Nonetheless, five years on and despite the return of democracy and the subsequent removal of sanctions and the issuing of an invitation to rejoin the PIF, Fiji has continued a pursuit of regionalism through alternative frameworks unabated and with continued vigour, attracting further members to the bodies Suva created. ${ }^{73}$ The implication is that Brij Lal's limited explanation for Fiji's end game does not hold salience, driving a search for an alternative explanation.

\footnotetext{
${ }^{67}$ Tarte, Regionalism and Changing regional order in the Pacific Islands, 313.

68 lbid.

69 Herr and Bergin, Our Near Abroad, 7.

70 Maclellan, Nic. "Stopping the cheques." Inside Story. August 04, 2017. Accessed October 27, 2017. http://insidestory.org.au/stopping-the-cheques/.

${ }^{71}$ Lal, Brij V. "Fiji: Fishing in Troubled Waters." Security Challenges 8, no. 4 (2012): 87.

Harvard

72 lbid,. 89.

${ }^{73}$ Gopal, Avinesh. "Palau joins PIDF." Fiji Times. November 17, 2017. Accessed November 17, 2017. http://www.fijitimes.com/story.aspx?id=424171.
} 
Challenges to order represent an attempt to permanently reshape the rules, institutions and power balance of an international system and the grounding upon which interactions between states are conducted. Stewart Patrick's treatise claims that these challenges are characterised by a situation where a state (or states) dissatisfied with their place within the existing international system (and who so considers it illegitimate) seek to rework the basis upon which diplomacy is conducted by overhauling or replacing the core institutions through which it interacts with others. According to Stewart, this occurs most often in the context of a rapid shift in power dynamics, where these dissatisfied parties seek to take advantage of these currents to reorder the system to their own preferences. ${ }^{74}$

By applying these concepts and criteria to the context of developments in the South Pacific, another explanation emerges. By continuing to pursue regionalism through alternative regional institutions even after sanctions and Fiji's suspension from the PIF were lifted indicates that Suva indeed seeks more than limited goals of sanctions evasion, but to rework the basis on which regional diplomacy is conducted. By doing so on the stated basis that alternative institutions would so better fulfil the "values and principles"75 that Bainimarama espoused, the implication would be for him to consider Fiji's previous partners and institutions illegitimate (that is, Fiji is unwilling to accept the existing regional roles of New Zealand and Australia). As this is further occurring within the midst of what Tarte described as an "increasingly dynamic and geo-economic landscape" 76 that is, of changing regional power dynamics (another element which according to Patrick, characterises a challenge to order) - Fiji's pursuit bears the hallmarks of not just sanctions resistance, but of a full-fledged challenge to regional order within the South Pacific.

\footnotetext{
74 Stewart,. 10.

${ }^{75}$ Bainimarama, UNGA address.

${ }^{76}$ Tarte, Regionalism and Changing regional order in the Pacific Islands, 312.
} 


\section{Chapter three - Developments within the South Pacific}

From 2006 onward, Fiji, under Frank Bainimarama's leadership, has undertaken a policy characterised by a willingness to challenge the authority of Australian-New Zealand sponsored regional organisations (most notably the PIF) and replace them with alternative frameworks. In practice, this strategy has been "most dramatically expressed" pursue an 'activist' foreign policy marked by lessening engagement in international organisations with significant New Zealand and Australian influence, deepening engagement in those without, and encouraging Fiji's Island neighbours to follow suit. ${ }^{78}$

According to Sandra Tarte, the core target of Fiji's regional policy has been the PIF, "Long regarded as the region's peak political body, with Australia and New Zealand as members."79 Concurrently, those regional organisations that have benefited most from Fiji's strategy are the Melanesian Spearhead Group (MSG), a pan-Melanesian grouping comprised of Fiji, Vanuatu, Solomon Islands and Papua New Guinea, which has experienced from a Fijian-led 'renaissance' in its relevance; ${ }^{80}$ as well as the Pacific Small Islands Development States (PSIDS) grouping at the United Nations, and the newly established Pacific Island Development Forum. ${ }^{81}$ Established in 2013 at Fiji's behest and composed of a membership of Pacific states exclusive of Australia and New Zealand, its foundation, in the aftermath of Fiji's 2009 expulsion from the Pacific Island Forum, the Pacific Island Development Forum (inclusive of the additional word "Development") has been viewed by commentators (despite Bainimarama's insistence to the contrary) as a direct challenge to the PIF ${ }^{82}$ - As Bainimarama himself stated,

Why do we need a new body, a new framework of cooperation? Because the existing regional structure for the past four decades — the Pacific Islands Forum

— is for governments only and has also come to be dominated only by a few. ${ }^{83}$

\footnotetext{
${ }^{77}$ Fry, Greg, and Sandra Tarte. The new Pacific diplomacy. ANU Press, 2016, 6.

78 lbid.

79 Tarte, Regionalism and Changing regional order in the Pacific Islands, 312.

${ }^{80}$ Fry and Tarte, New Pacific Diplomacy, 6.

81 lbid.

82 Ibid,. 9.

83 Nadi, Samisoni Pareti. "Fiji's push for alternative Pacific Islands Forum." ABC News. August 06, 2013.

Accessed May 29, 2017. http://www.abc.net.au/news/2013-08-06/fiji-forum/4867748.
} 
In one sense, asserting the inability of the Pacific Island Forum to serve Island interests, Bainimarama's actions nonetheless further assign a significant degree of importance to the Pacific Island Forum. In this, he implies at the shape and state of the existing regional frameworks and order that he seeks to challenge. Within this conception, the importance of the PIF is much as Tarte writes, where it exists as "the major avenue for the small Island states of Oceania to assert a collective voice on major international issues, thereby amplifying their voice and impact." 84 This importance assigned to the forum by Fiji is further evidenced in Graeme Dobell's interpretation that; "Fiji's declared starting point for talking to Australia about the future of Pacific regionalism is that Australia should leave the Pacific Islands Forum." 85

Of recent developments, Tarte declared the "inauguration in 2013 of the Pacific Islands Development Forum (PIDF) as potentially the most significant challenge to the PIF to date. Established by Pacific Island leaders in Fiji, it is based on a radically new approach to regionalism that includes Pacific Island state and non-state actors, and aims to become the institutional voice of PSIDS — at the global and wider regional levels.”

Through assigning said importance to regional bodies he conceived as vehicles for Australian and New Zealand regional dominance, Bainimarama sheds light upon how he views the regional order that he seeks to challenge. Much like the pervasion of formal international institutions as global indicators of an international order, Bainimarama's words and actions imply the operation of a distinct order within in the South Pacific region founded upon a plethora of regional institutions that frame and structure regional interstate interactions paramount among them the Pacific Island Forum. By labelling these institutions as dominated by "the few" (namely Wellington and Canberra) Bainimarama's implies that these regional institutions within the South Pacific exist (much per Mearsheimer's theories) ${ }^{86}$ solely to preserve the status and interests of the powerful players within a system. By rejecting the pursuit of regionalism within them on the claim that they do not adequately serve the interests

\footnotetext{
${ }^{84}$ Shibuya, Eric. "The problems and potential of the Pacific Islands forum." The Asia-Pacific: A region in transition (2004): 102.

85 Dobell, Graeme. "Australia, Fiji and Pacific regionalism." APSI Strategist. November 24, 2014. Accessed July 20, 2017. https://www.aspistrategist.org.au/australia-fiji-and-pacific-regionalism/.

${ }^{86}$ Mearsheimer, The false promise of international institutions, p. 5.
} 
of the South Pacific Islands ("the many"), the implication is that Fiji, considers the existing institutions of order within the South Pacific to lack legitimacy.

On this, the fact that Bainimarama has met some success in its endeavour, attracting a number of Pacific Island States into the PIDF, indicates that the perception it as a legitimate regional institution (and therefore that the PIF may not be completely legitimate) is not limited to Fiji, but is shared among Suva's Island neighbours. Nowhere was this more apparent than in the words of Tony De Brum, the Marshall Islands' representative to the PIDF's inaugural meeting:

"For too long we have accepted down as normal; we have accepted small as normal; we have accepted prescriptions of our development partners as normal — that we must do what we are told to do, not what we want to do. I came to this meeting in the hope that the PIDF will make up for that deficiency in our development; where solutions to our development problems can be reached quickly without multitudes of expensive consultants. The world needs alternative energy technology. This is something that can fit into the agenda of this meeting. We need to do something new about climate change. It is frustrating to Pacific Island countries that hardly anything has been done in that area. This organisation can take the lead in that and stop the rhetoric." 87

\section{Legitimacy and the historical institutions of regional order within the South Pacific}

In understanding as to how New Zealand and Australia lacked legitimacy within the South Pacific region enough for Bainimarama to launch his challenge and meet success, one must consider the history of its regional operation. Once regarded as a playground of colonial powers, Richard Herr wrote, "The Islands have not used their geography politically so much as they have been abused by it for centuries. The people of the Pacific Islands rarely have had the opportunity to shape their own destiny. Instead, outside actors have pursued their geopolitical interests at the expense of the Islands." 88 Where the region was decolonised around the 1960s and 70s, Tarte writes that a new regional order emerged. This was predicated upon "an extensive network of interconnected regional institutions, the most important of which being the Pacific Island Forum," comprising "the political leaders of all independent and selfgoverning states, together with Australia and New Zealand". 89

\footnotetext{
${ }^{87}$ Tarte, Sandra. "A New Pacific Regional Voice? The Pacific Islands Development Forum1." DIPLOMACY (2015): 79.

${ }^{88}$ Herr, Richard. "The Geopolitics of Pacific Islands' Regionalism: From Strategic Denial to the Pacific Plan." Fijian Studies: A Journal of Contemporary Fiji 4, no. 2 (2006): 111.

${ }^{89}$ Tarte, Regionalism and Changing regional order in the Pacific Islands, 314.
} 
Within this membership, the consequent disparities in the status and capabilities of the geographically isolated Island states on the one hand, and of New Zealand and Australia, have underpinned the region's unique power dynamics. While the Islands were underdeveloped, separated by vast distances, and since the close of the Japanese threat in 1945, largely absent of any material, resource or geographic capacity they could leverage to significant effect, New Zealand and Australia, both developed first world nations, did not share such concerns. In involving themselves in the post-colonial regional system in their 1971 establishment of the South Pacific Forum (later renamed the PIF), the existing literature suggests that New Zealand and Australia's motivations for not just participation but leadership in regional bodies in the aftermath of decolonisation was motivated by a series of strategic considerations. As Herr asserts, "By the mid-1970s, it was clear that there would be a fairly large number of exceptionally small and/or fragile states in the Pacific Islands Region. Concerns were raised initially when Tonga established relations with the USSR in 1976." 90 Both historic allies of the United States and supporters of the American led liberal world order, Australian and New Zealand's subsequent involvement in the region, was to an extent motivated by these considerations (though this did not foreclose the importance of other considerations). Consequently both would act as what Robert Ayson described as "Washington's leading allies in Asia-Pacific," 91 subordinate to the United States and according to Tarte, well placed to "maintain Western hegemony over the Pacific Island region, a legacy of the colonial era," ensuring the norms and rules of the post-war western-led global order were applicable to the South Pacific. ${ }^{92}$

Nonetheless, while the Australian-New Zealand regional system in the South Pacific has remained broadly reflective and supportive of the norms of the American led liberal world order (regardless of what party has taken power in either), ${ }^{93}$ that has not foreclosed the existence of several tensions and complexities in the relationship between these players. Throughout much of the Cold War period, New Zealand and Australia were formally bound to Washington in the ANZUS defense alliance, established in 1951 as a part of the U.S.' global efforts to form a united front against Communism. In the 1980s, New Zealand under David Lange newly elected Labour government faced pressures from activists within his own voter

\footnotetext{
${ }^{90}$ Herr, The Geopolitics of Pacific Regionalism, 115.

91 Ayson, Robert. "Choosing Ahead of Time?: Australia, New Zealand and the US-China Contest in Asia." Contemporary Southeast Asia: A Journal of International and Strategic Affairs 34, no. 3 (2012): 338.

92 Tarte, Regionalism and Changing regional order in the Pacific Islands, 314.

93 Tarte and Fry, The New Pacific Diplomacy, 14.
} 
base and party to ban visits by American ships carrying nuclear weapons. ${ }^{94} \mathrm{~A}$ position that gained the praise of the Soviet Union and the ire of both the United States and Australia (who proceeded to suspend its alliance commitments to New Zealand), this precipitated a number of intensified New Zealand led initiatives intent on banning the presence of nuclear weapons within the region ${ }^{95}$ - some of which received even Soviet signatures. ${ }^{96}$

Further, while Canberra and New Zealand, the inside players, have generally remained broadly in alignment in their regional policies, New Zealand and Australia have at times experienced tensions amid pursuits of divergent approaches. Tarte and Fry for example note that New Zealand has had a longer history of engagement with South Pacific regionalism, and that during the 60 s and 70s, openly assumed its role to be a unique one, closer to the islands than that of Australia. ${ }^{97}$ According to Australian Prime Minister John Howard, different self-perceptions were the divers of "Minor differences" in their regional policies. ${ }^{98}$ Notable examples of these differences were prevalent in their interventions in Bougainville and the Solomon Islands, where Australia's more aggressive and unilateral approaches earned them the reputations of "Good cop" and "Bad cop" respectively. 99 While New Zealand and Australia can be understood to have remained broadly in solidarity in their regional approaches and have remained so for decades, ${ }^{100}$ any credible analysis of their regional approaches must therefore take careful note of the subtle differences in the perceptions and underlying drivers in their policies and actions.

Broadly, to whence their regional leadership derived, Herr writes, "The Pacific Islands regional system would not be viable without Australian or New Zealand support."101 Together, both served as the foremost sources of "funding for the regional program and operating budget of the PIF Secretariat and related regional agencies." The result, as surmised by Tarte, "Australia

\footnotetext{
${ }^{94}$ Tow, William T. "The ANZUS dispute: testing US extended deterrence in alliance politics." Political Science Quarterly 104, no. 1 (1989): 120.

95 Thakur, Ramesh. "Creation of the Nuclear-Free New Zealand Myth: Brinkmanship without a Brink." Asian Survey 29, no. 10 (1989): 920.

${ }^{96}$ Fleron Jr, Frederic J., Erik P. Hoffmann, and Robbin F. Laird, eds. Contemporary Issues in Soviet Foreign Policy. Transaction Publishers, 1991. Pg 379.

97 Tarte and Fry, The New Pacific Diplomacy, 139.

98 Ibid,. 140.

99 Ibid,. 137.

100 Ibid,. 141.

101 "Australia's and NZ's Fiji policy weakened Forum, says academic." Radio New Zealand. March 04, 2013. Accessed July 30, 2017. http://www.radionz.co.nz/international/pacific-news/210637/australia's-and-nz's-fijipolicy-weakened-forum,-says-academic.
} 
and New Zealand held a special place... as the only non-Pacific Island members of the PIF and its secretariat. This gave them privileged access to, as well as influence over, regional actions and policy." 102 Indeed, the position and role of New Zealand and Australia within the South Pacific's institutional framework, and the role of the United States on the region's periphery, sheds light on both the relationship between global order and regional order within the South Pacific, and offers a practical case to support Stewart Patrick's assertion that powerful states create institutions of order to preserve their own interests. ${ }^{103}$

Further, it has traditionally been on that same basis that New Zealand and Australia have garnered the acceptance of the Pacific Islands states, and thus, their legitimacy within the region. A significant mechanism in the sustenance of international order both globally and regionally, where a regional system (or its institutions or frameworks) enjoys legitimacy, according to Kissinger ${ }^{104}$ and Weber, ${ }^{105}$ it implies the acceptance of the creators of order (the powers) by the smaller states within a system. Where they do not, and a regional order lacks legitimacy, it can engender and encourage challenges on the part of dissatisfied parties - as has happened with Fiji. A form of a soft, attractive, rather than hard coercive power, the level of willingness of states to accept another's authority cannot be definitively measured, though it can certainly be seen to exist on a spectrum. On that spectrum, it is evident in Bainimarama's successes within the region, that the legitimacy of the Australian-New Zealand led institutions has evidently diminished. Nevertheless, to understand in a clearer essence as to how this process occurred, it is necessary to explore as to where that legitimacy derived from in the past. Amid the global colonial retreat in the 1960s, several Pacific Islands (most having still not gained their independence) took up the same cause of independence that was in the period sweeping the world over, but which met with significant intransigence on the part of the colonial powers in the Pacific. ${ }^{106}$ Led by Fiji, several of the Islands demanded of the colonial powers, New Zealand and Australia among them, ${ }^{107}$ a greater role in both their own and regional affairs. Frustrated by the 'no discussion of politics' rule of the South Pacific Commission (a colonial-era regional institution and forerunner to the South Pacific forum),

\footnotetext{
102 Tarte, Regionalism and Changing regional order in the Pacific Islands, 314

103 Patrick, World Order, 103.

${ }^{104}$ Kissinger, World Order, 13.

105 Patrick, World Order, 10-11.

106 Shibuya, The problems and potential of the Pacific Islands forum, 104.

${ }^{107}$ Fry, Greg. "Politics of Regional Cooperation." In The South Pacific: Problems, Issues and Prospects, 169-81.

Palgrave McMillan, 1991.
} 
Ratu Mara, Fiji's prime minister, in the 1965 meeting of the commission, led what was called the Lae Rebellion. This consisted of five Pacific nations breaking from the commission to form their own regional body, the Pacific Island Producers Association (PIPA). In his demand for a changed regional framework, Mara remarked that "the powers seemed incapable of realizing that the winds of change had at last reached the South."108 This pivotal episode provides a historical showcase of Kissinger's assertion that challenges to international order occur where dissatisfied states pursue alternative principles of order and the predominant powers fail to comprehend the changing power dynamics ${ }^{109}$ (in this case, those brought about by the move to decolonisation). ${ }^{110}$ Further, the case demonstrates the salience of Kissinger's theories of international order within even the context of the tiny South Pacific. A relevant lesson from the region's past as to the consequences that have arisen where a regional body has lacked legitimacy (or acceptance) from the part of the Island states, this impasse was characterised by an unwillingness on the part of the small states to fully engage with the metropolitan powers for several years. It finally came to a conclusion with the establishment in 1971 of the South Pacific Forum (later renamed the PIF). ${ }^{111}$

The foundation of the South Pacific Forum (later the PIF) represented the starting point for the prevailing Australian-New Zealand led regional order, and a recognition of the considerations inherent in the Lae rebellion. While certainly created on one hand as a body that could serve New Zealand and Australia's regional security interests, the South Pacific Forum's 1971 establishment at Wellington and Canberra's behest represented a recognition of the need (on the part of Wellington and Canberra) to gain regional legitimacy were they to maintain those interests by offering concessions to the Islands that during the colonial era, did not exist. According to Greg Fry, the forum and the subsequent institutions of order that grew out of it "were not just created for the practical results they might achieve, they were also seen as symbols of an indigenous assertion of control over regional decision-making and activity"112 that could, according to Tarte, "influence governments both in the region and beyond."113 Much as with institutions the world over, these served to entrench the relationship between the

\footnotetext{
${ }^{108}$ Fry, Gregory E. "Regionalism and International Politics of the South Pacific." Pacific Affairs 54, no. 3 (1981):, 462.

${ }^{109}$ Kissinger, World Order, 366-367.

110 Tarte, Sandra. "Regionalism and globalism in the South Pacific." Development and Change 20, no. 2 (1989): 183.

111 Tavola, Kaliopate. "Re-thinking Pacific regional architecture whilst framing regional security." (2016).

112 Fry, Regionalism and International Politics of the South Pacific, 468.

113 Tarte, Regionalism and globalism in the South Pacific, 182.
} 
South Pacific states, assert their regional identity, define parameters of action for state parties and provide a framework for cooperation. In effect, they were accepted, according to Tarte, as "an important mechanism for asserting their newly acquired sovereign identities and claiming their rights as sovereign states." 114

Distant, disparate, and small in the size of their economies, populations and geographies, the Island states of the South Pacific have been largely reliant upon metropolitan powers to garner economic prosperity, stability, security and their connectedness with the outside world. Applied to the case of the South Pacific, it seems apparent that there is no exception - with questions of legitimacy within the region largely based around the scope within which the small, poorer Island states interact with the metropolitan powers (namely New Zealand and Australia). Consequently, legitimacy within the region (derived from the smaller states for the metropolitan powers) has been premised upon the extent to which the larger players have facilitated the ambitions of the Islands to attain these goals.

For New Zealand and Australia, this has for the most part taken the form of their material contributions toward the Islands states, the Pacific Island Forum and other regional bodies. As Greg Fry wrote; "The inescapable reality confronting the Pacific micro-states is their continuing economic dependence on larger states."115 According to Herr, "Arguably, the Pacific Islands regional system would not be viable without Australian or New Zealand support." The result, according to Herr and Bergin, was that "Australia (and New Zealand) devoted considerable resources to creating and supporting a regional system to express the Pacific Islands' common interests." ${ }^{116}$ Subsequently, they were accepted by the Islands on the basis that they were, according to Ratu Mara, necessary as partners in the region's development, ${ }^{117}$ "providing the largest share of funding for the regional program and operating budget of the PIF Secretariat and related regional agencies." 118 According to Herr and Bergin, this acceptance of their place within the regional system "was an extraordinary and singular act of faith in the bona fides of Australia as a legitimate member of the regional family. Australia's

\footnotetext{
114 Tarte, Regionalism and the Changing Regional Order in the South Pacific, 314.

${ }^{115}$ Fry, Regionalism and International Politics of the South Pacific Greg Fry, 456.

${ }^{116}$ Herr and Bergin, Our Near Abroad, 7.

${ }^{117}$ Comment by Ratu Sir Kamisese Mara, Prime Minister of Fiji, Grail Address, Corpus Christi College, Suva, 15 January 1973.

118 Tarte, Regionalism and the Changing Regional Order in the South Pacific, 314.
} 
inclusion came at the request of the Islands' leaders, who were pursuing a postcolonial agenda." 119

Overall, the picture of the prevailing regional order operating within the South Pacific is of one characterised by its formal institutions - at the centre of which stands the Pacific Island Forum. Doubtless influenced to some extent by outside factors and the American sponsored World order, the political makeup of the region is as much defined by political factors - namely membership within its regional institutions, as it is by Hedley Bull's shared commonalities. ${ }^{120}$ With the small Islands having, by virtue of their size and distance, historically lacked the capacity to create a strong regional framework of their own accord, New Zealand and Australia have, by virtue of their greater capabilities, been able to assert significant influence over the design and functioning of the regional system in favour of their own interests. Nonetheless, despite this hierarchical relationship, Wellington and Canberra's influence has been tempered by their willingness to legitimise their leadership among the Island states and not engender challenges similar to that of the Lae Rebellion - something they have done, at least in part, by providing material contributions.

\section{Heirachical regional systems}

The realities of this relationship imply at the operation of a regional order in the South Pacific much in line with Warren Zimmerman's theory of hierarchical regional systems. That is to say, it is composed of a great power (or in the case of the South Pacific - two with aligned policies, New Zealand and Australia), and a number of smaller states. ${ }^{121}$ While it would be difficult by any analysis to define New Zealand or Australia as global great powers, their position conforms to Jorge Pereira's definition of 'Regional Great Powers'. Defined as a state incapable of exercising significant weight by which they could define the scope of global institutions and power dynamics, their relative power in relation to their neighbours enables regional great powers "to affect them as if they were fully-fledged great powers." 122

According to Zimmerman, where a situation emerges much as it did within the South Pacific, where regional great powers emerge dominant over the rest of a number of smaller states, and

\footnotetext{
${ }^{119}$ Herr and Bergin, Our Near Abroad, 15.

${ }^{120}$ Bull, The Nature of Order in World Politics, 17.

${ }^{121}$ Zimmerman, William. "Hierarchical regional systems and the politics of system boundaries." International Organization 26, no. 1 (1972): 18-36.

122 Pereira, Jorge F. Garzón. "Hierarchical regional orders: An analytical framework." Journal of Policy Modeling 36 (2014): 27.
} 
simultaneously enjoy a degree of autonomy from other regions, he states that in the subsequent distribution of power, a number of scenarios could emerge with relation to the organisation of regional order. He writes, "Thinking in terms of ideal-types, 'hierarchical regional orders' could vary across a continuum between '(neo)-imperial regional formations', at one pole, and 'hierarchical regional societies', at the other. Whereas the former can be described as an extreme form of hierarchical relationship - commonly referred to in the literature as 'empire'; the latter can be conceived of as an ideal regional formation in which order is a 'contract' that permits both strong and weak states to attain valued foreign policy goals... (as well as) benign patterns of interaction defined by mechanisms and institutions that ensure power constraint."123 Within this framework, "claims of policy convergence are low or moderate both in scope and intensity, and those which are essential to the regional (great) power's grand strategy are predictable and part of the transactional bargain by virtue of which the smaller states are compensated in other issues of contention of their concern; the superior resources generated by the economies of scale of the regional (great) power flow toward the weaker states on a regular and reliable basis; and a set of institutional rules and norms that manage the use of preponderant power can be observed." 124

Needless to say, it is unlikely that any such regional order will fit perfectly into either arrangement and rather, the operation of regional order is far more likely to exist on different levels upon a spectrum. For example, during the Cold War, the Soviet-led hierarchical order in Eastern Europe approached far closer the neo-imperial model. This arrangement is perfectly evidenced as Triska wrote, by the Soviet Union's insistence that “the eight political systems (of the East Bloc)... (changing) their political structures and institutions, their values relevant to politics, their social and economic formations, and their policies." ${ }^{125}$ At the other end of the spectrum, Brazil's institution building in the South American regional order is far more emblematic of a benign hierarchical regional system. Taking special care to refrain from claims of policy convergence, ${ }^{126}$ Brasilia has "Instead it has engaged in a multilateral and at times cumbersome process of consensus-building with its weaker neighbours,"127 investing in

\footnotetext{
123 Ibid.

124 Ibid, 38.

125 Triska, Jan F. Dominant powers and subordinate states: the United States in Latin America and the Soviet Union in Eastern Europe. Duke University Press Books, 1986, pg 2.

${ }^{126}$ Burges, Sean W. "Without sticks or carrots: Brazilian leadership in South America during the Cardoso Era, 1992-2003." Bulletin of Latin American Research 25, no. 1 (2006):, 29.

${ }^{127}$ Pereira, Hierarchical Regional Orders, 41.
} 
regional institutions that serve to constrain Brazil's power and provide a level of predictability to its neighbours. 128

\section{The South Pacific contract}

Applied to the context of the South Pacific, it is evident that in the pre-Lae rebellion, colonial era, the structure of regional order approach reflected a much more Pereira's neo-imperial formation whereupon the Islands held limited say in their own affairs and were exploited for strategic and material offerings, ${ }^{129}$ albeit ones that were significantly limited in the context of the Pacific Ocean. ${ }^{130}$ Nonetheless, from the foundation of the South Pacific Forum in 1971 onward, in order to legitimise their continued regional leadership, New Zealand and Australia have established a regional arrangement largely conforming to Zimmerman's contract theory. ${ }^{131}$ In effect, while New Zealand and Australia, both regional great powers, have shaped the scope of regional frameworks within the South Pacific to favour their interests, they have done so only with the consent of the Islands and thus gain their participation within it by an implicit contract, that when breached, would signify their loss of legitimacy.

This implicit contract was predicated upon New Zealand and Australia's supporting the Island states goals of fully exercising their rights to sovereignty and amplifying their influence globally through utilising their collective weight. For the most part, this took the form of material contributions and providing constitutional assistance, though likewise, much as with Pereira's theory, ${ }^{132}$ both had to accept institutional constraints upon their ability to utilise coercive power. In practical terms, this was expressed in the informal mechanism of the "Pacific Way" - described by Michael Has as “a system of 'unanimous compromise,' where everyone sacrifices something for the overall benefit of the whole and all decisions are made by consensus." ${ }^{133}$ A clear constraint absent from the colonial era institutions, the impact of this mechanism is evident in Eric Shibuya's observation that it effectively created "the ability of single nations to exercise a de facto veto, thereby watering down (Pacific Island) Forum statements for the sake of 'Pacific Way' consensus." 134 Overall (though with some inevitable exceptions), by remaining sensitive to Pacific Affairs - and thus not impinging upon the

\footnotetext{
128 Ibid.

129 Ibid,.., 29.

130 Lawson, Stephanie. "The military versus democracy in Fiji: Problems for contemporary political development." The military and democracy in Asia and the Pacific (2004), 131.

${ }^{131}$ Zimmerman, Hierarchical regional systems and the politics of system boundaries.

132 Ibid, 36.

133 Shibuya, The Problems and Potential of the Pacific Islands Forum, 103.

134 lbid,. 106.
} 
'Pacific Way', New Zealand and Australia lent legitimacy to their involvement, and thus the structure of the regional order as a whole.

Further, this implied contract, whereupon the regional great powers accepted limits on their actions was apparent in the historical conduct of New Zealand's diplomats. In 1987, Wellington's Foreign Minister, Russell Marshall stated, "Whatever our Western constitutional anxieties might be, we have to be careful (that) what we do does not make us sound white, guilty, patronising, and having a neo-colonialist attitude." ${ }^{135}$ Further, such efforts are evident in New Zealand's particular efforts to identify herself as a part of its neighbours. According to Anna Powles, “A 1984 report by the Ministry of Foreign Affairs examining New Zealand's relations with its Pacific neighbours declared as one of its assumptions that "New Zealand should recognize that we are part of the Pacific." ${ }^{136}$ This sentiment was echoed in 2002 by then Foreign Minister Phil Goff, "We see ourselves as a Pacific nation with key responsibilities in the South Pacific." 137

To this, New Zealand and Australia's right to lead the region (at least in the eyes of the Islands) was predicated upon an implicit contract. In Bainimarama's challenges to the legitimacy of the existing institutions of order, as well as his successes in bringing some of the other Island states into his alternative framework, implies that it had been breached. From this, it infers that his challenge and his successes thus far originated, at least in part, from that breach. Indeed as Tarte notes, in the years preceding Bainimarama's developments, the regional system, "built upon the idea of Pacific Island ownership of regional organisations," had suffered from "tensions and contradictions... eroding its political legitimacy and integrity." "138 She notes that the prime example of this was a trend toward the increasingly assertive role played by New Zealand and Australia, described by Firth as a "shift toward a new, Australian-directed regionalism."139

\footnotetext{
135 Alley, Roderic. "The 1987 military coups in Fiji: the regional implications." The Contemporary Pacific (1990): 50.

136 Powles, Anna. "Finding Common Ground: New Zealand and Regional Security Cooperation in the Pacific." Regionalism, Security and Cooperation in Oceania. (2015): 81.

137 Ibid.

138 Tarte, Regionalism and the Changing Regional Order in the South Pacific, 314.

${ }^{139}$ Firth, Stewart. Intervention and State-building in the Pacific: The Legitimacy of co-operative Intervention'. Manchester: Manchester University Press, 2008, 122.
} 


\section{The contract's breach - how the prevailing regional order lost legitimacy}

A contradiction of the premise of the "Pacific Island Ownership" upon which the post-1971 regional system was built, it is not difficult to see how New Zealand and Australia's increasing regional assertiveness diminished their legitimacy. Occurring over a significant period of time, cracks in the South Pacific Order were apparent as early as 1987, when New Zealand Prime Minister David Lange responded aggressively to Fiji's coup (led by indigenous Fijian nationalists who had overthrown a largely Fiji-Indian backed government, and who enjoyed some sympathy throughout the Islands). This triggered warnings from Australia's Foreign minister Bill Hayden that the continued pursuit of a strategy unpopular among the Islands might prove a hindrance to Wellington and Canberra's security interests and facilitate greater Libyan involvement in the region. ${ }^{140}$ A practical reference toward the importance of legitimacy in the maintenance of a South Pacific regional order, and historic acknowledgement of the implications that could arise from its loss, Australia was herself nonetheless, not immune to similar miscalculations that could impinge upon Canberra's own legitimacy. In 1994, Australia's minister for Pacific Affairs, George Bilney, would call upon the Island states to reform their bureaucracies, garnering criticism from scholar Greg Fry for "telling people in other countries how to run their places... (in what amounted to) public humiliation." 141

The scope of these tensions and contradictions escalated following a series of regional security crises in the late 1990s and early 2000s. Amid a backdrop of 9/11 and a series of coups, ethnic conflicts and riots within the South Pacific, concerns arose in Canberra that the South Pacific was fast transforming into an "arc of instability" where the risk of state failure was high. Were the Islands to fail, so said both policy-makers and academics of the day, it ran the risk of generating refugee, organised crime and terrorist cell flows throughout the region, which could, in turn, pose a threat to both New Zealand and Australia's security. The remedy practised by New Zealand and Australia was a focus on promoting 'good governance' reforms throughout the South Pacific and through providing regional assistance to states deemed most at risk (notably the RAMSI mission to the Solomon Islands). Generally, this was inclusive of a stronger promotion of liberal ideals including human rights, a focus on anti-corruption, and market-oriented economic reform. Broadly, these reforms were often pursued at the expense

\footnotetext{
140 Roderick, The 1987 military coups in Fiji: the regional implications, 38.

${ }^{141}$ Smyth, Rosaleen, Nii-K. Plange, and Neil Burdess. "Big brother? Australia's image in the south pacific." Australian Journal of International Affairs 51, no. 1 (1997): 39.
} 
of considerations of non-interference and considerations of sovereignty - a state formalised in the forum leaders' signing of the 2000 Biketawa Declaration and the 2004 Pacific Plan, committing the Island states to these reforms and creating a framework for intervention. ${ }^{142}$

While these developments occurred in the formal context of a broad regional consensus, they were for the most part, pursued primarily by New Zealand and Australia with sometimes only the reluctant support of some of the Islands. ${ }^{143}$ A further case to support Mearscheimer's assertion that international institutions exist to serve the interests of their creators (in this case, the Bitekawa Declaration and Pacific Plans), New Zealand and Australia's changed focus within the regional institutions of the South Pacific to face post cold-war challenges (particularly in the security realm) mirrored similar Western-led developments. Characterised by an assertiveness that included conditions being attached to aid transfers and the insertion of Australian and New Zealand human capital into the governments of many Island states, these trends occured both as a part of, and concurrently to the United States led shift in global institutions (e.g. through the creation of the World Trade Organisation, responsibility to protect doctrine etc.). This new assertiveness was justified by Australia's Prime Minister John Howard on the basis that "it is in Australia's interests and in the interests of our Pacific Island neighbours to strive for a region that is economically viable, politically stable and free from crime. The financial costs and potential threats to Australia from failing states, including transnational crime and international terrorism, would be immense." 144145

While generally considered necessary by Wellington and Canberra for the region's continued stable development, ${ }^{146}$ the manner in which those often painful reforms were pursued - through attaching it as conditions to aid transfers, as well as through agenda setting within the regional bodies created significant disquiet among the Island ranks. In 2001, Ratu Mara confessed his "sense of disappointment with our metropolitan members (of the Pacific Island Forum, New

\footnotetext{
142 Firth, Stewart. "A reflection on South Pacific regional security, mid-2000 to mid-2001." (2001): 278.

143 Ibid, 280.

144 Brown, Peter. "Australian influence in the South Pacific." Australian Defence Force Journal 189 (2012): 66.

145 Lum, Thomas, and Bruce Vaughn. "The Southwest Pacific: US interests and China's growing

influence." China-US Economic and Geopolitical Relations (2007): 20.

146 Roberts, Susan M., Sarah Wright, and Phillip O'Neill. "Good governance in the Pacific? Ambivalence and possibility." Geoforum 38, no. 5 (2007): 971-972.
} 
Zealand and Australia) ... that they have sought to impose their solutions in an insensitive way, when left to ourselves we could work things out in what we have called the Pacific Way."147

According to Penjueli and Morgan, the perceived insensitivity and brevity with which New Zealand and Australia pursued neo-liberal and good governance reforms was "condoned, if not actively facilitated, by a Forum Secretariat that many Pacific Islanders increasingly regard as being in the pockets of Australia and New Zealand."148 The result was that in pursuing a process aimed at protecting and democratically legitimising the regional system, New Zealand and Australia inadvertently undermined it - damaging its own legitimacy through actions that served to create the perception of neo-colonial overreach and insensitivity. Overall, the effect was to create fertile ground upon which Bainimarama could build and grow Island support for the PIDF and his alternative institutions of regional order.

Further to these developments, one cannot foreclose the role of both identities and climate change in delegitimising both New Zealand and Australia within the South Pacific region. While for decades, New Zealand has (much like with Ministers Goff and Marshall's statements) sought to express a common identity with the South Pacific Islands, Bainimarama has sought to downplay the extent of this relationship. According to Hedley Bull, societies of states are formed where groups of states become conscious of their commonalities, their shared histories, cultures and civilizational development. ${ }^{149}$ Unlike the Islands, (and while significantly different from each other) New Zealand and Australia can both be broadly characterised as post-colonial, developed and populated states with populations of primarily European descent, ${ }^{150}$ and thus their self-identification as an integral part of a South Pacific identity has always been (at least among the Islands) strenuous at best. A vulnerability always present in New Zealand and Australia's legitimacy within the region (as is evident in the particular efforts by New Zealand to identify itself as a part of it), Bainimarama, in seeking to undermine their legitimacy by emphasising their aloofness. In refusing a 2016 invitation to rejoin the Pacific Island Forum, Bainimarama expressed that New Zealand and Australia were

\footnotetext{
${ }^{147}$ Mara, Ratu. "Keynote Address on the Occasion of the 30th Anniversary of the South Pacific Forum of Leaders 2001." Speech, Nauru, Yaren, August 17, 2001. Accessed April 8, 2017.

http://www.pireport.org/articles/2001/08/17/keynote-address-he-rt-hon-ratu-sir-kamisese-mara.

148 Penjueli M, Morgan W "Speaking Truth to Power: Australian and New Zealand Use of Power Politics to Launch Pacific Free Trade Negotiations." Pacific Network on Globalisation, (2009) in Tarte, Regionalism and the Changing Regional Order in the South Pacific, 315.

149 Bull, The Nature of Order in World Politics, 28.

150 Powles, Finding Common Ground: New Zealand and Regional Security Cooperation in the Pacific, 82.
} 
"not Pacific Islanders". On that basis, he claimed he would be "unable to attend myself because of the refusal of Australia and New Zealand to step back and allow the Pacific Island nations to determine their own futures free from outside interference." ${ }^{\prime 151}$ In effect, this was a direct contravention and challenge to the claims of New Zealand that it was a part of a pan-Pacific identity, and thus an attack on Wellington's legitimacy. At its meetings, Fiji's representatives have continued this line, expressing that if Wellington and Canberra are to retain a presence, China should also be invited. The implication of this is to signal Fiji's intent and view that New Zealand and Australia should only have so much influence as other, 'outside' players - in essence challenging the notion that the two were constituent, and therefore, legitimate parts of the South Pacific and rather, painting them as peripheral to it.

Likewise, no discussion of legitimacy within the South Pacific is complete without consideration of the issue of climate change, and New Zealand and Australia's perceived lack of action on it. Like the issue of perceived domination by New Zealand and Australia, this perception drew from a long history, with Eric Shibuya for example in 2004 stating that "Australia has hurt its image by holding fast on the issue of climate change." To this, he pointed to a prime example from 1997, where Australia's Prime Minister John Howard was unwilling to agree to any binding targets for greenhouse emissions set by the Pacific Island forum owing to its capacity to damage Australia's economy. ${ }^{152}$ The result was to cause Tuvalan Prime Minister Bikenibeu Paeniu's to remark that Australia "dominates us so much in this region. For once, we would have liked to have got some respect." ${ }^{" 153}$ With climate change a significant priority of the Islands owing to their vulnerability to rising sea levels, its pertinence within the region was particularly evident in Kiribati President Anote Tong's claim: "We have no choice but to engage even more aggressively internationally because the key to our survival will depend on whether international action is taken on climate change or not." 154 In relation to Bainimarama's challenge, the particular damage and vulnerability done to New Zealand and Australia's legitimacy was underlined in Bainimarama's 2016 letter explaining his boycott of that year's Pacific Island Forum. In this, he claimed that Wellington and Canberra's climate

\footnotetext{
151 "They are not Pacific Islanders' - Frank Bainimarama wants NZ, Aust out of Pacific Forum." 1 NEWS NOW. September 9, 2016. Accessed September 02, 2017. https://www.tvnz.co.nz/one-news/new-zealand/they-notpacific-Islanders-frank-bainimarama-wants-nz-aust-forum.

152 Shibuya, The Problems and Potential of the Pacific Islands Forum, 9.

153 Hussein, Bernadette. "The Big Retreat." Pacific Islands Monthly, November 1997, 11.

154 Tong, Anote, "Keynote Address at the Launch of the Pacific International Relations Forum". 9 October, Suva, October 2012. Accessed July 04 2017. <http://pidp.eastwestcenter.org/pireport/2012/October/10-11-sp.htm>.
} 
change policies were "clearly not in the interests of the Pacific small Island developing states," 155 a direct challenge to the legitimacy of their leadership. As was evidenced at the PIDF's inaugural forum, these perceptions were not limited to Fiji but shared among many of the Islands, with the Marshall Islands representative stating that; "We need to do something new about climate change. This organisation can take the lead in that and stop the rhetoric."156

\section{The role of legitimacy in Fiji's challenge to order}

Overall, New Zealand and Australia's declining legitimacy, a trend clear in both academic literature on the topic and within the statements of the South Pacific states' leaders, has played a significant part in Bainimarama's attempts to challenge the regional frameworks that permeate the South Pacific and establish alternative ones. Since the establishment of the Pacific Island Development Forum in 2013, Bainimarama in justifying his enterprise has cited New Zealand and Australia's domination of the Pacific Island Forum and their failure to adequately address regional challenges (particularly so of climate change). ${ }^{157}$ Stating at its inaugural meeting; "Why do we need a new body, a new framework of cooperation? Because the existing regional structure for the past four decades - the Pacific Islands Forum - is for Governments only and has also come to be dominated only by a few. In too many instances, it no longer genuinely represents our interests and needs," and that "we are doing it in the Pacific Way," it is evident that Bainimarama has paid attention to considerations of legitimacy in both challenging the existing regional framework and in creating an alternative one.

Suspended by New Zealand and Australia from the Pacific Island Forum in 2009 for a failure to hold elections, Bainimarama was pressured into pursuing regional interests through alternative frameworks - namely the PIDF and MSG. ${ }^{158}$ Nonetheless, while Suva's suspension proved a catalyst for Fiji's strategy of challenging and seeking to replace the existing Australian-New Zealand leg regional frameworks, it is unlikely Bainimarama would have met significant success without the necessary condition of the commonhold perception among the Islands that Wellington and Canberra had acted outside the boundaries of acceptable

\footnotetext{
155 Martin, Lisa. "Fiji PM blames Australia, NZ for forum boycott." Stuff. September 9, 2015. Accessed May 02 , 2017. http://www.stuff.co.nz/world/south-pacific/71908160/fiji-pm-blames-australia-nz-for-forum-boycott. 156 Tarte, Sandra. "New regional Pacific voice? An observer's perspective on the Pacific Islands Development Forum (PIDF), inaugural summit, Denarau, Fiji, 5-7 August 2013." (2013). 157 "Prime Minister Bainimarama Address at the inaugural Pacific Islands Development Forum Meeting." Fiji Government Online Portal. August 5, 2013. Accessed March 02, 2017. http://www.fiji.gov.fj/MediaCenter/Speeches/ADDRESS-AT-THE-INAUGURAL-PACIFIC-ISLANDS-DEVELOPME.aspx. 158 Tarte, Regionalism and Changing Regional Order in the Pacific Islands, 312-313.
} 
approaches toward regional affairs - that is, if the legitimacy they had previously enjoyed when perceived as supporters of the Islands had not diminished. Indeed, one may be able to speculate that Fiji would have, had those conditions not been met, promptly returned to the existing Australian-New Zealand led regional frameworks (including the PIF) when the opportunity was presented - something Brij Lal suggested would happen in 2012. ${ }^{159}$ The fact that Fiji has not only failed to do so but continues to intensify its strategy, indicates, much like with Tarte's observation, that Fiji seeks a greater transformation of the regional order itself.

By pursuing its regional policies through institutions absent of New Zealand and Australia, the intended effect is to strip both of their leadership and membership within the South Pacific order, and banishing them to its periphery. Within the residual margins of a South Pacific absent of Wellington and Canberra, Fiji and the Islands would feasibly be able to offer a greater focus upon those same goals that led to the establishment of the South Pacific Forum. These were, to realise Pacific Ownership of the region, to address challenges of sustainable development and climate change and to amplify the South Pacific's voice on the global stage (the latter of which Suva has already demonstrated through its successes within the UN and G77). ${ }^{160}$ Offering a framework geared primarily toward the achievement of these goals (rather than secondarily, like the PIF and Australian-New Zealand led framework), it is on this basis that Fiji legitimacy for its framework and leadership in the form of the acceptance of the Islands. By in effect removing New Zealand and Australia from the equation, this would effectively reduce the scope of the South Pacific's relationship to the Western liberal order worldwide. Where New Zealand and Australia were present, it had effectively ensured the functioning of a hierarchical regional order. In the absence of both, the power differential between the remaining leading nations, Fiji, Papua New Guinea, Tonga and Samoa, and of the smaller Islands is nowhere near so pertinent. The result is to circumcise the capacity for the larger players to dominate their smaller neighbours.

While Fiji's alternative framework does not foreclose the continued existence of a hierarchical system and regional great powers like in Zimmerman's thesis ${ }^{161}$ (the mantle would instead likely fall to Suva, Port Moresby, Apia and Nuku'alofa), it would severely constrain its capacity to operate on a hegemonic, neo-imperial basis. Indeed, some commentators have speculated on

\footnotetext{
159 Lal, Brij V. "Fiji: Fishing in Troubled Waters." Security Challenges 8, no. 4 (2012): 85-91.

160 Tarte, Regionalism and Changing Regional Order in the Pacific Islands, 313.

${ }^{161}$ Zimmerman, Hierarchical regional systems and the politics of system boundaries.
} 
the possibility for competition between Fiji and Papua New Guinea, ${ }^{162} 163$ implying that within a revised regional order, there is potential for the emergence of a balance of power mechanism. Additionally, one cannot ignore the pertinence of considerations and motivations unique to Fiji itself. Like with Mearsheimer's claim that institutions exist to preserve the status and interests of the powerful players within a system, ${ }^{164}$ it is true that within the margins of a South Pacific regional institution absent of New Zealand and Australia, Fiji would be one of its most powerful players. In this situation, Suva could (like New Zealand and Australia did with the Pacific Island Forum) shape it toward its own interests (ones that Bainimarama sees as evidently in alignment with those of the other Islands), an obvious additional motivation underpinning Fiji's changed strategies.

\footnotetext{
162 Hayward-Jones, J., and T. Newton Cain. "Pacific Island Leadership: PNG steps up." The Interpreter. Available at: www. lowyinterpreter. org/post/2014/08/28/Pacific-Island-leadership-PNG-steps-up. aspx (2014). 163 Hayward-Jones, Jenny. Big enough for all of us: Geo-strategic competition in the Pacific Islands. Sydney: Lowy Institute for International Policy, 2013.

${ }^{164}$ Mearsheimer, The false promise of international institutions, p. 5.
} 


\section{Chapter four - The role of power in the South Pacific}

Recent developments provide a strong case to demonstrate the importance of legitimacy to regional order and the maintenance of international institutions. Over the past several decades, it is evident that New Zealand and Australia, as well as their respective institutions' loss of legitimacy in the region, endangered their long-term sustainability as regional leaders. Nonetheless, while hugely significant in understanding regional developments, the relationship of legitimacy toward Fiji's challenge to regional order still only explains a part of the context in which they occurred and are still occurring - One cannot forget the basis on why, at its establishment, both New Zealand and Australia were initially welcomed. With the Islands impoverished and underdeveloped, Wellington and Canberra's presence considered necessary to ensure the creation of a regional system within the South Pacific by the virtue that they could provide the material contributions (aid, funding etc.) necessary for that system's creation that the Islands could not. That such a factor has not proven salient in Fiji's challenge, implies, much in line with Patrick Stewart's theory that challenges to order occur primarily within power transitions as rising states seek to realign institutions to serve their interests, ${ }^{165}$ that the power dynamics of the South Pacific have experienced significant change.

In his 2016 treatise, Patrick Stewart emphasised the importance of the relationship between power and international order, stating, "Historically, great powers have been the makers of world order, the weak the takers. More interesting are the would-be breakers, dissatisfied states pursuing alternative principles of world order." 166 Within the case of the Pacific, the development of the regional system over the past forty years demonstrates the applicability of his thesis to the regional level, with New Zealand and Australia, as regional great powers, playing the role of the creators of order, the Pacific Islands, the weaker states and the role of takers, and Fiji, the breakers. He states that where these challenges occur, it is generally "during rapid power transitions, as emerging powers seek to alter or replace regnant rules to conform to their own distinctive preferences." 167 The reason for this observation is simple, while weak states may seek a revised regional order, generally they lack the material capacity to bend the institutions of order to their will (for instance, Iran is not likely to bring about UNSC reform in the foreseeable future). On the other hand, the powerful states within a system generally have

\footnotetext{
165 Patrick, World Order, 10.

166 Ibid.

167 Ibid.
} 
much greater capacity to displace them. While during a gradual power transition, the institutions of order are given a much greater scope to evolve to the changing dynamics, during rapid shifts, the great powers are far more prone to, as Kissinger states, "prove unable to adapt the system's equilibrium to incorporate (the challenger's) rise." 168

Applied to the South Pacific, in the fact that Fiji has been able to establish a credible alternative regional system, resist New Zealand and Australia's sanctions, and garner significant success within it (for instance, in attracting many other Pacific states into that system's institutions) implies such a transition has taken place. However, little to no academic literature exists to make the claim that the often unstable and coup-prone Fiji has experienced a rise to ascendancy that would have encouraged and enabled it to launch a credible challenge to the prevailing, Australian-New Zealand led regional order. Nonetheless, there is significant literature attributing these changes to the rapid rise and entry into the region of the so-called "new players' of the Peoples Republic of China, Russia, Indonesia, India and others. ${ }^{169} 170171$

\section{China's rise and its influence on the South Pacific}

Historically, the South Pacific has remained, perceived both politically and academically, as an "American lake," 172 home to a regional order heavily subordinate to that of the Western, liberal world. However, at the Cold War's conclusion, the need for a regional policy of strategic denial diminished, resulting in significant cuts to American aid to the region. ${ }^{173}$ This factor was compounded by further developments in recent years, where a series of literature and commentators have hailed a recent shift whereupon thanks to the growing presence of external players in the region (most notably China), the power dynamics within the South Pacific have significantly changed. The reasons for these developments are twofold. Where on the one hand, China, Russia, India and others have expanded into the South Pacific in pursuit of UN votes, allies and resources, Fiji has likewise actively sought their support in pursuit of

\footnotetext{
168 Kissinger, World Order, 210

169 Tarte, Regionalism and Changing Regional Order in the Pacific Islands, 320.

170 Haywood-Jones, Big Enough for All of Us: Geo-Strategic Competition in the Pacific Islands.

${ }^{171}$ Wesley-Smith, Terence. "China's rise in Oceania: Issues and perspectives." Pacific Affairs 86, no. 2 (2013): 351-372.

172 "A brief history of America in the Pacific." The Economist. April 22, 2017. Accessed July 02, 2017. http://www.economist.com/news/special-report/21720716-how-manifest-destiny-pushed-west-sea-briefhistory-america-pacific.

${ }^{173}$ Fry, Greg. "Framing the Islands: Knowledge and Power in Changing Australian Images of" the South Pacific"." The Contemporary Pacific (1997): 320.
} 
alternative sources of aid and allies. According to Haywood-Jones ${ }^{174}$ and Wesley Smith ${ }^{175}$, whatever hidden or open intentions may underpin these processes (and the three offer different explanations), they have nonetheless offered heightened capabilities to the Islands (and Fiji in particular). The result was to dilute New Zealand and Australia's regional influence (as well as that of the United States), creating a shift in power dynamics that has, according to Michael O'Keefe, a "facilitating environment"176 (whether intended or not) Fiji's challenge to regional order.

A long-standing foreign policy objective of both pre-Bainimarama Fiji and many other Island states, attempts to diversify relations with outside players to the region (China often foremost among them) has long offered the Island states the promise of greater independence from Wellington and Canberra. ${ }^{177}$ Before his government's overthrow by Bainimarama in 2006, Fiji's foreign minister Kaliopate Tavola had, in opening Fiji's Beijing embassy, praised the "Asian Countries' good approach diplomatically and politically of non-interference."178 Hinting at Fiji's displeasure at the lack of non-interference practised by New Zealand and Australia, Tavola spoke on the occasion of the need to diversify relations away from the two. Nonetheless, (in spite of implying of New Zealand and Australia's diminishing legitimacy) the foreign minister struck a conciliatory tone, stating that relations with its traditional partners would "remain strong" and that "like any good neighbours, we quarrel at times." 179

Following Bainimarama's 2006 takeover and Fiji's removal from the South Pacific Forum, this tone changed (implying further of his intent in supplanting rather than changing the existing regional order). In a 2008 meeting with Chinese officials in Beijing, Fiji's new leader, Bainimarama, stated, "Fiji will not forget that when other countries were quick to condemn us following the events of 1987, 2000 and in 2006, China and other friends in Asia demonstrated a more understanding and sensitive approach to events in Fiji." ${ }^{180}$ A consequence at least in part attributable to Fiji's search for alternative sources of aid, trade, investment and tourism into the region under the pressures of diplomatic isolation and sanctions imposed by Wellington

\footnotetext{
174 Haywood-Jones, Big Enough for All of Us: Geo-Strategic Competition in the Pacific Islands.

175 Wesley-Smith, China's Rise in Oceania: Issues and Perspectives.

176 Tarte and Fry, The New Pacific Diplomacy, 8.

177 Tarte, Sandra. "Fiji's Look North Strategy and the role of China." In China in Oceania: Reshaping the Pacific? 2010, 118.

178 Ibid,. 121.

179 Ibid.

180 Yang, Jian. "China in Fiji: displacing traditional players?." Australian Journal of International Affairs 65, no. 3 (2011): 306.
} 
and Canberra, Fiji's intensified post-2006 attempts to seek deepened relations with China and others, termed the "Look North Policy" has borne significant fruit. In the year since Bainimarama's ascension to power, Beijing's aid to Fiji rapidly increased from \$23 million per year to $\$ 161$ Million. ${ }^{181}$ Concurrently, Beijing has provided significant support and training opportunities to the Fijian military, ultimately filling much of the void left by Wellington and Canberra's sanctions. In the decade since, Chinese aid to the region (excluding low-interest loans) would total some NZ \$2.54 Billion, including 400 million to Fiji and 700 million to Papua New Guinea. ${ }^{182}$

Owing to the small size of the Pacific nations both in their populations and economies, what to the likes of Beijing might be considered a small aid contribution still has the capacity to drastically alter regional dynamics. ${ }^{183}$ By providing support to post-coup Fiji in addition to the other Islands (as well as institutions through which Suva is pursuing alternative principles of order including the PIDF and MSG), Suva has circumcised the effects of Wellington and Canberra's sanctions. The consequence is to offer Fiji and the Islands a form of pure material power through which they have been able to act with significantly greater independence from Wellington and Canberra and withstand unwanted directives from both. Throwing the winds of enhanced material capabilities to the sails of Fiji's challenge while further enhancing the credibility of its challenge, this change in power dynamics has proven a key driver in Fiji's successes thus far.

\section{Beijing's motivations - A Chinese challenge to the regional and global order?}

A case in how changing power dynamics have given root to a challenge to regional order, more pertinent to discussions about China (and others) contributions to the region are questions about their own intentions. An area of limited strategic interest and activities of China (and indeed, the Soviet Union and Russia) for decades, academic discourse on this matter has previously attributed this interest primarily to narrow concerns about fishing rights and the Taiwan

\footnotetext{
181 Ibid,. 305.

182 Murphy, Tim. "Why China is splashing cash around in the Pacific." Newsroom. May 22, 2017. Accessed August 02, 2017. https://www.newsroom.co.nz/2017/05/15/23681/chinese-money-is-changing-the-faceof-the-south-pacific.

183 Windybank, Susan. "The China syndrome [China's growing presence in the Southwest Pacific.]." Policy: $A$ Journal of Public Policy and Ideas 21, no. 2 (2005): 28.
} 
issue. ${ }^{184} 185186$ While the potential for China to challenge Western interests in the region has long been noted, ${ }^{187}$ these discussions (at least prior to 2006) have generally remained speculative rather than based on any current assessment of Chinese activities. However, with the recent increase in aid to the region, and with that lacking the conditions (generally of 'good governance' reform and human rights promotion) inherent in Australia and New Zealand's aid contributions to the region, these developments have caused significant disquiet. Most scholars have dismissed any talk of Beijing engaging in geo-strategic competition in the Pacific ${ }^{188}$ (as was typical in the region in the 19th century era of colonisation) in the immediate term. However, China's long-term strategy has been the subject of further debate and speculation amid simmering suspicions that Beijing is deliberately seeking to displace the liberal-led order within the South Pacific.

Ultimately, the answer to this dilemma implies poses significant consequences and challenges to the future of both regional and global order. Should China not be seeking to challenge regional order within the South Pacific, then these developments could be conceptualised as a purely Fijian-driven enterprise occurring largely in isolation aimed at reshaping the South Pacific order to favour the Islands (and Fiji in particular) further. Should it not, then the role being played by Fiji could thus be viewed in a prism similar to the roles played by New Zealand and Australia - as agents of great powers (namely China) ultimately seeking to displace a regional component in the liberal-led American World Order by reducing the influence of Washington's regional allies. Doing so in a part of the world where Beijing has had few interests previously, it would be difficult to determine how such a move could be determined as defensive. This therefore implies the possibility that developments in the South Pacific represents the beginnings or even a testing ground (on a micro scale reflective of the region's size), of a broader, Chinese challenge to the American-led liberal world order.

\footnotetext{
184 Ibid.

185 Dobell, Graeme. China and Taiwan in the South Pacific: Diplomatic chess versus Pacific political rugby. Sydney: Lowy Institute for International Policy, 2007.

${ }^{186}$ Biddick, Thomas V. "Diplomatic rivalry in the South Pacific: the PRC and Taiwan." Asian Survey 29, no. 8 (1989): 800-815.

187 Godley, Michael. "China the Waking Giant." Foreign Forces in Pacific Politics (1983): 130-142.

188 Tarte, Fiji's Look North Strategy and the role of China, 118.
} 
Long considered a possibility by, among others, Ikenberry, ${ }^{189}$ Mearscheimer ${ }^{190}$ and Patrick Stewart ${ }^{191}$, discussion about a potential Chinese challenge to world order have been predicated upon claims that the institutions of the existing liberal led world order, being constructed by the United States, does not adequately serve Chinese interests. Broadly, this theory owes itself to the claim that at the end of the Cold War, the absense of a balance of power led to subsequent unilateral moves by the United States and its allies toward norms of contingent sovereignty (to deal with modern security, transnational and human rights challenges). Concurrently, in moving away from norms of the infallibility of sovereignty, this view holds that in the eyes of China and other rising powers, the legitimacy of the American-led order has diminished. ${ }^{192}$ According to this theory (termed China Threat Theory), as Beijing continues to accumulate further economic and military power, it will ultimately, upon finding the existing institutions of world order unable to adapt to meet its rise, seek to challenge them and replace them with ones that better serve its interests. ${ }^{193}$ Opponents of this theory argue instead for a peaceful Chinese rise, where Beijing will adopt the institutions of the existing global order that will, in turn, adapt to meet this rise. ${ }^{194}$

Applied to the context of its activities in the South Pacific, Fiji has continually justified its venture on the basis of viewpoints (on issues of sovereignty and non-interference) like those expressed by the Chinese leadership - similarities that Bainimarama has made particular note to emphasise. In China's provision of support to Fiji (particularly controversial elements such as its military) has not only strengthened those institutions of order China so desires, but weakened those emblematic of the post-Cold War American-led liberal order (institutions that New Zealand and Australia are the strongest defenders of within the South Pacific). In doing so, Beijing has raised concerns that it is seeking to challenge America's strategic position within in the South Pacific, a feeling echoed in 2011, by Secretary of State Hillary Clinton toward the U.S. Senate's Committee for Foreign Relations. ${ }^{195}$ This would thereby imply that Beijing is seeking to challenge American hegemony (at least within the South Pacific and

\footnotetext{
189 Ikenberry, Liberal Leviathan.

190 Mearsheimer, John J. "The future of the American pacifier." Foreign Affairs (2001): 46-61.

191 Patrick, World Order, 20.

192 Ikenberry, G. John. "Power and liberal order: America's postwar world order in transition." International Relations of the Asia-Pacific 5, no. 2 (2005): 144-145.

193 Broomfield, Emma V. "Perceptions of danger: The China threat theory." Journal of Contemporary China 12, no. 35 (2003): 265-284.

194 Al-Rodhan, Khalid R. "A critique of the China threat theory: A systematic analysis." Asian Perspective (2007): 41-66.

195 Haywood-Jones, Big Enough for All of Us: Geo-Strategic Competition in the Pacific Islands.
} 
possibly beyond it) and replace those institutions emblematic of the American-led liberal world order with some more reflective of Chinese preferences.

Nonetheless, this thesis does not find much support in the literature, with most scholarship characterising Beijing's increased aid transfers, investment in infrastructure projects, and intensified diplomatic presence in the region as typical of its activities elsewhere through the developing world. As Fergus Hanson posits, "China's defence aspirations in the South Pacific are likely to remain limited. Any significant military move by China in the region would be counterproductive." 196 Obvious motivations of opening new trading partners and avenues through which China can access resources aside, most scholars have cited the challenge posed by the substantial Taiwanese influence in the region and the substantial voting power per capita held by the numerous Pacific states in international organisations (which could be gained at relatively little cost) as the key sources of Beijing's intensified interest. ${ }^{197}{ }^{198}$ While its activities may have altered regional dynamics to the point where they offered Fiji the capabilities to launch a own credible challenge, this would imply that China's activities are not conducive to Beijing seeking to challenge order (either globally or within the South Pacific) but rather far more narrow goals. Variants of this case are supported throughout much of the related literature. Hameiri, for example, argues that China's intensified aid transfers and diplomatic inroads into the region is not motivated by a wish to displace or supplant either the traditional players or the existing regional order. Rather, he assumes that Brautigam's thesis on Chinese activities in Africa is also salient for the South Pacific - that is, that the impression that Beijing is engaging in strategic competition owes to a failure by media outlets and other observers to separate aid payments from normal profit investment. ${ }^{199}$ Further, Yongjin Zhang argues that Beijing does not seek strategic competition, or hegemony, as evidenced largely by the lack of willingness by China to greater more responsibility for regional affairs. ${ }^{200}$ Finally, WesleySmith notes that despite the sound of alarms bells at China's engagement with the Fijian military, Beijing has "been at pains not to over-exploit the opportunity for regional influence

\footnotetext{
196 Hanson, Fergus. "The dragon in the Pacific: more opportunity than threat." (2008).

197 Windybank, Susan. "The China syndrome [China's growing presence in the Southwest Pacific.]." Policy: $A$ Journal of Public Policy and Ideas 21, no. 2 (2005): 33.

198 Hanson, The dragon in the Pacific.

199 Hameiri, Shahar. "China's 'charm offensive'in the Pacific and Australia's regional order." The Pacific Review 28, no. 5 (2015):, 638.

${ }^{200}$ Zhang, Yongjin. "China and the emerging regional order in the South Pacific." Australian Journal of International Affairs 61, no. 3 (2007): 367.
} 
provided by the former military commander and current Prime Minister Frank Bainimarama so as to avoid any direct confrontation with Fiji's traditional partners.” 201

The implication of this case (that China's involvement is motivated by benign intentioned) is that the thrust of the challenge to the regional order witnessed in the region over the past decade originates not from Beijing, but rather, is occurring at the initiative of Suva. In further evidence of this, Fiji has, according to Hameiri, made significant efforts (for instance through inviting Chinese leaders to the region and supporting the 2008 crackdown in Lhasa) to make its relationship with China appear closer than it really is. The purpose is to leverage regional influence and to prevent Australia from interfering in Fiji's internal governance processes. ${ }^{202}$ While this offers the impression that China is supportive of Fiji's challenge to the regional order, the reality is far more nuanced. For example, Fiji notably diverged from Beijing's position on the South China Sea issue, ${ }^{203}$ and despite Beijing's continued 'unaccountable' and 'irresponsible' ${ }^{204}$ (according to Wellington and Canberra) aid and investment to the Islands, China appears to remain, at least for the short term, for the most part disengaged from any direct attempts to supplant New Zealand and Australia's (deputised) authority.

Further, one cannot gain a full contextual understanding of Chinese interests in the South Pacific without considering the significance of Beijing's bilateral relationships with both Australia and New Zealand. Both developed nations (unlike the aid-receiving Island states) in $2011^{205}$ and $2015^{206}$ Australia and New Zealand respectively held high-level talks with Beijing on defence cooperation, while both enjoy substantial trade ties and agreements that dwarf those between Beijing and any of the Island states. With the scope of these relations and the volume of bilateral trade having expanded substantially over the past 20 years (albeit not so suddenly as they did with Fiji), 207208 these military, economic and diplomatic interests would likely be

\footnotetext{
201 Wesley-Smith, Terence. "Geopolitics, Self-Determination, and China's Rise in Oceania." In Self-determinable Development of Small Islands. Springer Singapore, 2016, pg 89.

202 Hameiri, China's charm offensive, 649.

${ }^{203}$ Fox, Liam. "China miscalculates Fijian support for South China Sea claims." ABC News. April 15, 2016. Accessed October 20, 2017. http://www.abc.net.au/news/programs/pacific-beat/2016-04-15/chinamiscalculates-fijian-support-for-south-china/7331030.

${ }^{204}$ Hameiri, China's charm offensive, 634.

205 Medcalf, R. "Australia-China defence ties: Beyond the hype. The Interpreter. Retrieved March 8, 2017." (2011).

${ }^{206}$ Gulliver, Aimee. "Gerry Brownlee meeting military leaders in China." Stuff. September 27, 2015. Accessed August 02, 2017. http://www.stuff.co.nz/national/politics/72454358/gerry-brownlee-meeting-militaryleaders-in-china.

207 Brady, Anne-Marie. "New Zealand-China relations: Common points and differences." (2008).

${ }^{208}$ White, Hugh. "The limits to optimism: Australia and the rise of China." Australian Journal of International Affairs 59, no. 4 (2005): 469-470.
} 
further compromised were China to overtly challenge New Zealand and Australia's positions and institutions within the region. One thereby might expect a Chinese strategy intent on reducing U.S. influence to instead or likewise be predicated on an attempt to drive a wedge between the U.S. and its regional allies (a topic that while interesting - is owing to its complexities, far too complex to be discussed in-depth within the scope of this thesis).

Nonetheless, while a significant portion of the existing scholarship concludes on this basis that Chinese activities in the South Pacific represent nothing out of the ordinary and merely the continued pursuit of its 'normal' foreign policy goals indicates that China does not seek to challenge the regional order, that does not foreclose the possibility of Beijing leveraging its increased presence to do so in future. For example, Jiang Yang, a long-time proponent of the peaceful China theory, conceded that Beijing's growing diplomatic influence in the present might in future provide opportunities to turn that influence into dominance should there be a significant shift in the global balance of power. ${ }^{209}$ While China's shows of deference toward Australian, New Zealand and American interests in the region may indicate a lack of a preference toward who leads the South Pacific regional order, even the most basic analysis of the situation would suggest Beijing could exercise far more influence within a Fijian-led order than one led by New Zealand and Australia.

Considering this, it is plausible that China's shows of deference could represent an attempt to merely offer the impression that Beijing is disinvested in Fiji's challenge. If China was to launch an overt display of support to Suva, it could risk not only engaging Washington, Wellington and Canberra in opposition, but should that challenge fail, Beijing would risk losing the influence it already has. Further, to do so might delegitimise this alternative order on the basis that it would weaken Fiji's claim to be leading a genuinely Pacific order. So far, China has framed the motivations behind its intensified cooperation and non-conditional support to the region as deriving from a number of normal, seemingly benign and nothing-out-of-theordinary motivations. These include to Beijing's competition with Taiwan, and its assumption that, as China is the de-facto leader of the developing world, it must extend its relations with developing states worldwide, and its longstanding (arguably millennia old) commitment to principles of non-interference in the affairs of far-flung states. ${ }^{210}$ In Fiji in particular, China finds a regional hub, home of the headquarters of many regional organisations, and the largest

\footnotetext{
${ }^{209}$ Yang, China in Fiji: displacing traditional players, 320.

${ }^{210}$ Hameiri, China's charm offensive, 645.
} 
of the Island states, and therefore the optimal base from which to extend its regional relations. ${ }^{211}$ While this is undoubtedly to an extent true, if China's motivations extend further - for instance, to establishing herself a foothold from which will later be optimally placed to challenge the American-led order both in the region and the world in future, then Beijing's current displays of deference ensures that whatever party (be it Fiji or New Zealand and Australia) emerges dominant within the ongoing struggle between Suva and Wellington and Canberra for a South Pacific regional order, China, by not engaging in any activities likely to set off alarm bells of security fears in Washington, Wellington or Canberra, will not create any reason to be seen as an enemy, and will continue to exercise influence regardless. Consequently, Beijing can preserve its bilateral relationships with all the parties no matter the outcome. Likewise, in limiting its present involvement, Beijing does in no way undermine Fiji's claim to be heading institutions indigenous to the South Pacific. Within that margin, China ensures that, Fiji can continue to provide indigenous leadership, and claim legitimacy on that basis. Contrarily, were Beijing to deepen its involvement, it is plausible that the Islands would view the challenge as another foreign-imposed enterprise, undermining the legitimate basis on which Fiji has launched its challenge to begin with.

Reconciling both Mearsheimer's offensive neorealist theory that states will invariably seek hegemony in pursuit of their own security, ${ }^{212} 213$ as well as the practical observations of much of the existing literature on China's activities in the South Pacific, by this theory (that China's activities do not represent a challenge to order, but rather an attempt to position herself for a future challenge), it is feasible to expect that Beijing might equip Bainimarama with enough resources that he might keep his challenge alive. As is clear from the current situation, Fiji's challenge is far from complete, and while Suva has met with successes to far, it has a long way to go before it can definitively claim to have supplanted the prevailing Australian-New Zealand led order. While Suva has attracted some 14 Pacific Islands to the PIDF, ${ }^{214}$ the PIF has 18 state parties, ${ }^{215}$ and save for Fiji, most have remained happy to maintain membership in both. This was evidenced in a number of statements by participants at the forum, notably in the words of

\footnotetext{
${ }^{211}$ Ratuva, Steven. "A New Regional Cold War? American and Chinese Posturing in the Pacific." Asia \& the Pacific Policy Studies1, no. 2 (2014):, 412.

212 Mearsheimer, John J. "China's unpeaceful rise." Current History - New York. 690 (2006): 160.

${ }^{213}$ Mearsheimer, John J. The tragedy of great power politics. WW Norton \& Company, 2001.

${ }^{214}$ Gopal, Palau joins PIDF.

215 "Forum Communique - Fourty Seventh Pacific Island Forum." Pacific Islands Forum. September 10, 2016. Accessed November 17, 2017. http://www.forumsec.org/resources/uploads/embeds/file/2016_Forum_Communique_11sept(1).pdf.
} 
Solomon Islands Prime Minister Gordon Darcy Lilo at the PIDF's first meeting, where he claimed that there was room for both the PIF and PIDF, stating, "The Pacific Islands Development Forum is a discussion forum, it's addressing development issues facing the countries and it's geared up towards sharing ideas, approaches, experiences, as to how countries can adopt and grow to sustain the natural environment but encourage more social and economic development for their people. The Pacific Islands Forum is a leaders' forum, the leaders themselves make their own agenda, and there are rules and processes and procedures that govern the way leaders meet and decide on issues." Further, a particular example of the core limitations of Fiji's alternative framework could be found in the points raised by the respectives delegates of the Marshall Islands and Micronesia at the PIDF's inaugural meeting, at which both stated that the question of long term funding (indeed, a form of material power), would need to be resolved were the body (and with it, Fiji's alternative regional order) to have a future.

In note of it, simultaneously, China would not be expected to inject so much that it could provoke alarm bells in Wellington, Canberra or Washington, causing them to view it as a hostile rival intent on supplanting their influence with Beijing's. With China's current strategy posing few risks in the short term, should the existing regional or global dynamics experience a further change in Beijing's favour - for instance, by its continued rise or by an American retreat from South East Asia, China's current strategy would leave it optimally placed to establish herself as a regional hegemon in future.

On these considerations, one can conclude that the thrust of the challenge to regional order is occurring at the initiative of Suva and not Beijing. Therefore, these developments within the South Pacific do not in any way (yet) represent a smaller part of a challenge to the Americanled world order. Nonetheless, it is certainly feasible (albeit speculative) as to whether China's motivations within the region stretch further - and that China's support to Bainimarama's revisionist government may still represent, much in line with Sun Tzu's maxim, "All warfare is the art of deception," 216 an attempt to furtively support Fiji's challenge while simultaneously allaying American, Australian or New Zealand security fears and thus responses. Through its strategy, China will be able to position herself exceptionally well for a future challenge to the prevailing order (both in the region and the world) while simultaneously ensuring that Beijing does not risk losing its influence should Fiji be unsuccessful.

${ }^{216}$ Tzu, Sun. The art of war. Shambhala Publications, 2005, 12. 


\section{Chapter Five: Conclusions - The future of order in the South Pacific and beyond}

Regional developments within the South Pacific have offered a practical showcase of numerous theories of international order. With far-reaching consequences for the future of the region and New Zealand and Australia's influence within it and globally, the case offers significant lessons for the maintenance of the liberal international order both within the South Pacific and further afar.

A small and yet distinctive region of the world politically, culturally and historically, within the South Pacific, international order has existed within it much in line with scholarly observations about its operation the world over. That is to say, it has provided a level of predictability that serves the interests of states bound by a series of shared geographic, political and historical factors apart of the regional system, and further, it is invested in a framework of interconnected regional organisations (that is institutions). Centred on the Pacific Island Forum, the foremost institution of order within the South Pacific, these regional organisations were created and underpinned by the material power and capabilities of the regional Great Powers (and allies of the U.S.); New Zealand and Australia - the founders and funders of the regional system. Much in line with Mearsheimer's general theories about international institutions and great powers, ${ }^{217}$ it is evident that those within the South Pacific were established to serve primarily the regional great powers' (Australia and New Zealand, and on the region's periphery the U.S.') interests. In particular, their purpose was to ensure their continued monopoly over regional security, the amplification of their voice on the global stage, and the spread of the American-led liberal global order over the region.

Established in response to the declining legitimacy and subsequent challenge to a colonial-era order and institutions in the 1960s and 70s, the Australian-New Zealand led regional order traditionally garnered legitimacy and with it, stability through a series of concessions to the Island states that the colonial era frameworks lacked. The new frameworks in effect enabled the smaller Island states to expand their global influence and exercise their rights as sovereign states to the fullest extent possible. With the capacity of the regional great powers to exercise their capabilities for coercion circumcised through the mechanism of the 'Pacific Way,' and with New Zealand and Australia providing significant material contributions toward helping the Islands realise their goals as newly sovereign states to amplify their voice on the global stage, the relationship that existed between the regional great powers and the small states within

${ }^{217}$ Mearsheimer, The false promise of international institutions. 
the South Pacific was, while hierarchical, much in line with that Pereria described as a benign regional system ${ }^{218}$. That is to say, that it was characterised by institutional constraints limiting the regional great powers capacity to dominate the region, and substantial material flows from the regional great powers toward the smaller players.

A consequence of a challenge to the colonial era order, the formation of the prevailing order in the South Pacific in the 1960s and 70s occurred in a process much as Kissinger theorised about order generally - that "order is submerged, (it is not from) military defeat or an imbalance in resources, but from a failure to understand the nature and scope of the challenge arrayed against it." ${ }^{219}$ In the case of the South Pacific, this was evident, where, according to the chief architect of that challenge (Ratu Mara), the colonial powers, and creators of that order, failed to appreciate the breadth of the Island demands for independence within a world fast moving away from colonialism.

From approximately 2006, following Bainimarama's coup and onward, regional developments have mirrored both that earlier challenge as well as Kissinger's theories of challenges to international order, where, "the moral right of the creators of order (New Zealand and Australia) to exist and act in a manner that until the challenge, has been treated as beyond question" 220 has been under assault by a Fiji claiming the prevailing order is illegitimate and intent on establishing a regional system complete with its own alternative formal institutions that would banish New Zealand and Australia to its periphery.

This challenge has manifested in Fiji's attempts to pursue regionalism through alternative institutions of order; this can be attributed to Fiji's dissatisfaction with the institutions of the prevailing order in a period where a rapid shift in power dynamics has offered Suva (previously lacking) capabilities to challenge them. From the 1980s onward, New Zealand and Australia, in addition to the regional institutions they lead, have suffered from a diminishing legitimacy. With both's claims of both to being apart of a Pacific identity contentious at best, (an inherent vulnerability of the South Pacific order to begin with) this diminishing legitimacy can generally be attributed to the compounding of this factor with the growth of a number of further, (not baseless) perceptions from the Islands. Firstly, that they were not adequately pursuing the interests of the Islands (for instance on issues of climate change); secondly, there was a feeling present among the Islands that New Zealand and Australia did not respect the sovereignty and

\footnotetext{
218 Pereira, Hierarchical Regional Orders, 41.

${ }^{219}$ Kissinger, World Order, 211.

220 Ibid.
} 
independence of the Islands or constraining mechanisms such as the Pacific Way. The reasons behind this can in part be attributed to New Zealand and Australia's aggressive pursuit of "Good Governance reforms" in response to a number of post-cold war security challenges. These responses apparently did not share as much support among the Islands as they did in New Zealand and Australia- in effect, demonstrating the salience of Mearsheimer's theory of international order that great powers can and will unilaterally change the institutions of order to suit their changed interests. ${ }^{221}$ Concurrently, the traditional regional dominance of New Zealand and Australia and their capacity to coerce the Islands through various carrots and sticks has been significantly diluted thanks to the growing regional interests of multiple rising powers, foremost among them China.

Each examined in turn with respect to the institutions that permeate the South Pacific, these two concepts, legitimacy and power, shed light on the movements underpinning Fiji's foreign policy strategies. Together, developments in the scope of both undermined the foundations upon which the post-colonial Australian-New Zealand led regional order and its institutions within the South Pacific have been traditionally grounded upon. These factors created optimum grounds for a challenge to regional order - the trigger for which was Fiji's 2006 coup and New Zealand and Australia's immediate response, that is to sanction Fiji and suspend it from the primary institution of regional order - the Pacific Island Forum. Evidently, these actions largely failed to appreciate the extent to which regional power dynamics had shifted and the extent to which Wellington and Canberra's legitimacy (as well as that of the ideals they promoted) had foundered. Further, Fiji's suspension served to further delegitimise their claims to be leading a Pacific institution in that it excluded from it the largest and most developed of the Island states. Largely lacking capacity to force the desired changes within the scope of the existing Australian-New Zealand led institutions, Fiji's pursuit of regionalism through alternative regional institutions absent of Australia and New Zealand was most notably expressed in the newly founded Pacific Island Development Forum. The obvious result of this strategy was to lessen the extent of Australia and New Zealand's influence within the region by weakening the authority of their institutions and decision-making structures. Establishing these bodies with specific reference to both Australia and New Zealand's increasingly dominant role and their perceived failure to address regional issues, it is clear that Bainimarama's claims that New Zealand and Australia and their institutional frameworks are illegitimate have gained some

${ }^{221}$ Mearsheimer, The false promise of international institutions. 
traction. This is evidenced in a number of developments. Notably, these include PIDF having attracted international recognition as the representative of the South Pacific in the UN, and Fiji's successes in attracting the presence and support of both numerous external states to meetings of its bodies, as well as numerous Island states - many of which signified their satisfaction with the institutions of Fiji's envisioned regional order as providing an alternative to the Australian- New Zealand led ones. In these successes, the case further demonstrating the salience of Kissinger's claim that successful challenges often most occur in the midst of rapid power transitions where the existing powers fail to comprehend the challenge arrayed against them. ${ }^{222}$

Nonetheless, Fiji's challenge is so far only partially successful or complete. While Fiji has gained members and supporters within its institutions, most state parties (Fiji excluded) retain membership in the Pacific Island Forum and the Australian-New Zealand led regional order it composes the centre of. This implies at something of an indifference among the Islands toward Fiji's challenge to regional order, whereupon many of the Islands neither support nor oppose it, but will rather seek to pursue their interests in either the Australian-New Zealand or the Fijian-led frameworks depending on the extent to which either serves their interests of the day.

Overall, understanding these developments within a framework of international order paints a picture of a challenge to regional order where, Suva, despite its successes, is still largely unable to supplant the entire weight of Wellington and Canberra's material capabilities. From this, Fiji is at present, still unable to establish its bodies as the unquestioned primary institutions through which regionalism is pursued throughout the South Pacific. Consequently, order in the South Pacific can be understood to presently exist in something of a state of flux or hybrid - where two conceptions of order compete for relevance. Nonetheless, regardless of which emerges dominant, it is evident that Australia and New Zealand's regional influence has significantly diminished - from which a number of lessons on international order can be drawn for both within the region and beyond it.

In the way of practical implications, both Wellington and Canberra have reactively adjusted their policies toward Fiji, dropping sanctions after elections were held (with credible voting, though which hardly possessed the attributes of fairness) $)^{223}$ and extending an invitation to Suva

\footnotetext{
222 Kissinger, World Order, 366-367.

${ }^{223}$ Fraenkel, Jon. "The Remorseless Power of Incumbency in Fiji's September 2014 Election." The Round Table 104, no. 2 (2015): 151.
} 
to rejoin the South Pacific Forum. ${ }^{224}$ However, these have, contrary to Brij Lal's predictions, ${ }^{225}$ failed to halt Fiji's strategy. Rather, Fiji has continued its pursuit of regionalism through the PIDF, and the other institutions emblematic of its revisionist order, all of which continue to grow in relevance - as evidenced by their continued growth of membership and support. ${ }^{226}$ Indeed, should regional power dynamics shift further in Fiji's favour, it is likely that its challenge (and the relevance of its rival institutions) will meet with further success, feasibly to the point where they could unquestionably be seen as having supplanted the Pacific Island forum and with it, the Australian-New Zealand led regional order - an outcome that is undoubtedly Suva's goal. Within these circumstances, the extent to which the American-led liberal order covers the South Pacific would be diminished, and New Zealand and Australia's capacity to shape posterity within the South Pacific would be reduced to a fraction of their past influence. Within these margins, both Wellington and Canberra could be left far more vulnerable to foreign security threats - and potentially at the mercy of a regional security framework led by Fiji. Additionally, while it is difficult, considering the existing evidence, to hold China (or any of the other rising powers) primarily liable for these developments, the result of them is that they have garnered a significant regional foothold, from which if China seeks to challenge the regional or global American led liberal order in future, it is well placed to do so - something that would likely be more possible should Fiji meet further success in displacing the existing order.

In relation to the implications of Fiji's developments for the state of Global international order, it is curious that trends within the region have mirrored the theories of numerous scholars on the current state of the global, liberal American-led order. Much as has occurred within the (American subordinate order within the) South Pacific, many scholars (including Ikenberry, Kissinger and Patrick) have observed that the global American-led liberal order is suffering from a combination of diminishing legitimacy. They theorise that this is occuring within a context of changing power dynamics that are quickly curtailing the dominance of the liberal powers and which will likely engender a challenge to the Western World order in future. Generally, the reasons behind these are much the same globally as they are within the South Pacific - where the traditional great powers recent responses to post-cold war security

\footnotetext{
224 Patterson, Jane. "NZ, Australia lift Fiji travel ban." Radio New Zealand. March 31, 2014. Accessed October 05, 2017. http://www.radionz.co.nz/news/political/240284/nz,-australia-lift-fiji-travel-ban. 225 Lal, Fiji: Fishing in Troubled Waters.

${ }^{226}$ Cava, Litia. "PIDF Welcomes New Members." Fiji Sun. February 9, 2016. Accessed October 05, 2017. http://fijisun.com.fj/2016/02/09/pidf-welcomes-new-members/.
} 
challenges have in essence, unilaterally diminished the significance of considerations of sovereignty as an international norm - undermining their own legitimacy. Concurrently, like within the South Pacific, this has occurred within the context of their diminishing power in relation to the rest of the world, with a number of rising powers, China foremost among them, fast gaining greater power and diluting the capacity of the traditional great powers (e.g. The United States, Britain, France) to coerce others. In reflecting on developments within the South Pacific, the foremost implication is to demonstrate, within a smaller regional context, the salience of these theories. The broader implication of this is that unless adjustments are to be made to the global American-led liberal order, similar developments, will as the literature suggests, play out within the scope of a challenge to the global international order.

Within the South Pacific, Fiji's challenge, and its successes thus far, have occurred largely because of Australia and New Zealand's failure to recognise and address these changes (both in the power dynamics and in the changed perceptions of their roles) by adapting the institutions of order to these new realities. This was particularly evident in their decision to sanction Fiji, an action which had little impact thanks to the changed power dynamics, but which did serve to further Suva's resentment and drive to challenge the existing order. Occurring in the context of a cultural divide evidently not given adequate consideration by Australia and New Zealand, those values and principles both assertively pursued in their 'Good Governance' approaches and imposition of sanctions on Fiji, while important to Canberra and Wellington, evidently did not share the same pertinence among the Islands. While in the past, it may have been possible to overcome a Fijian challenge to order predicated on this basis, the changed power dynamics of the modern South Pacific, something not fully accounted for in Australia and New Zealand's initial response, have presented a far more difficult task.

In lacking the legitimacy they once enjoyed, Australia and New Zealand engendered a challenge to their authority, and indeed the regional order, something that occurred as soon as the compounding factors of change in power dynamics and the relevant pressures allowed it. Whether Wellington and Canberra can reverse the effects of this challenge remains to be seen - though Fiji has expressed no willingness to rejoin the Pacific Island Forum and with it, the Australia-New Zealand led regional order - Australia and New Zealand retain several significant carrots that could be leveraged to do so in future. The goal here would thus be to recreate a willingness on the part of the Island states to accept the structures established by the Wellington and Canberra - in essence, to legitimise their authority once again. 
Beyond the significant levels of material aid they can and have contributed toward the Islands (including to Fiji in the way of disaster relief), personal ties between Australia, New Zealand, Fiji and many of the other Island states remain strong. Many Fijians (and other Pacific Islanders), including much of Fiji's ruling coalition were educated in Australia and New Zealand, while emigration has left large diaspora populations in both - a possible form of leverage that China and others lack. ${ }^{227}$ As Powles writes; "New Zealand sits both within the region, but also on the periphery. A colonial history, current constitutional obligations, and its role as a development donor to the region, places New Zealand alongside Australia with the regional periphery powers of France, United Kingdom, and the United States. Geography, culture and historical linkages therefore serve to situate New Zealand in the region and on its periphery." ${ }^{228}$ In future, these factors could potentially prove crucial in bringing Fiji back from its challenge and reincorporating Suva into an adapted existing regional framework (led by Australia and New Zealand).

On a global scale, as Kissinger observed, the existing rules of the global world order were created by the Western liberal powers and so reflect their preferences. He writes,
"The frequent exhortations for countries to "do their fair share," play by "twenty-first- century rules," or be "responsible stakeholders" in a common system reflect the fact that there is no shared definition of the system or understanding of what a "fair" contribution would be. Outside the Western world, regions that have played a minimal role in these rules' original formulation question their validity in their present form and have made clear that they would work to modify them. Thus while "the international community" is invoked perhaps more insistently now than in any other era, it presents no clear or agreed set of goals, methods, or limits." 229

Overall, the lessons derivable from these developments are clear. Over the past few decades, developments in the Pacific have played out on a microscale almost to the letter of Ikenberry's, Kissinger's, Patrick and others' warnings about the vulnerabilities of the global American-led liberal order (due to its declining legitimacy and the concurrent rise of multiple new powers). The effect is to demonstrate their salience and adding further credibility to the case that if these trends (of diminishing legitimacy and relative power) at a global level continue, then the United States and its allies will need to adapt the scope of world order to the new realities. As applies

\footnotetext{
227 Powles, Finding Common Ground, 84.

228 Ibid.

${ }^{229}$ Kissinger, World Order, III.
} 
just as well to the South Pacific as it does to the Global American-led liberal world order, the continued maintenance of the prevailing order requires a practical accommodation of the realities of the changed $21^{\text {st }}$ century power dynamics and the divergent cultural convictions of the Islands (within the South Pacific) and rising powers (globally) on one hand, and of the Liberal powers (of which the United States, Australia and New Zealand are apart) on another - it does not require, according to Kissinger, "a moral insight."230

The lesson of the South Pacific case to global order is simple: if the American-led liberal order does make such adjustments, it risks facing those patterns that have played out in the South Pacific occurring on a global scale - that is, that it could engender a challenge from the likes of China or another rising power on a global level not dissimilar to that launched by Fiji toward the Australian-New Zealand led regional order - something that, with respect to China and the United States' much larger capabilities, could prove enormously devastating should it erupt into conflict. To the form those adjustments should take, it is clear that, much like with Stewart Patrick's claim, "legitimacy will be needed over the long haul to sustain an open, liberal international order" 231 - with the realities of modern power dynamics recognised and accounted for with respect to the divergent attitudes and conceptions of what constitutes legitimacy. As Kissinger wrote, "In our time, the quest for world order will require relating the perceptions of societies whose realities have largely been self-contained. The mystery to be overcome is one all peoples share - how divergent historic experiences and values can be shaped into a common order." 232

\footnotetext{
${ }^{230} \mathrm{Ibid}, .10$.

231 Patrick, World Order, 23.

232 Kissinger, World Order, 13.
} 


\section{Bibliography}

"A brief history of America in the Pacific." The Economist. April 22, 2017. Accessed July 02, 2017. http://www.economist.com/news/special-report/21720716-how-manifest-destiny-pushed-west-sea-

brief-history-america-pacific.

"Australia's and NZ's Fiji policy weakened Forum, says academic." Radio New Zealand. March 04, 2013. Accessed July 30, 2017. http://www.radionz.co.nz/international/pacificnews/210637/australia's-and-nz's-fiji-policy-weakened-forum,-says-academic.

"Prime Minister Bainimarama Address at the inaugural Pacific Islands Development Forum Meeting." Fiji Government Online Portal. August 5, 2013. Accessed March 02, 2017. http://www.fiji.gov.fj/Media-Center/Speeches/ADDRESS-AT-THE-INAUGURAL-

PACIFIC-ISLANDS-DEVELOPME.aspx.

"Sabotage claim as Nadi summit winds up." ABC News. August 07, 2013. Accessed August 02, 2017. http://www.abc.net.au/news/2013-08-08/an-pacific-Islands-development-forumwrap/4873060.

"'They are not Pacific Islanders' - Frank Bainimarama wants NZ, Aust out of Pacific Forum." 1 NEWS NOW. September 9, 2016. Accessed September 02, 2017. https://www.tvnz.co.nz/one-news/new-zealand/they-not-pacific-Islanders-frankbainimarama-wants-nz-aust-forum.

Alagappa, Muthiah. "Regionalism and conflict management: a framework for analysis." Review of International Studies 21, no. 4 (1995): 359-387.

Alley, Roderic. "The 1987 military coups in Fiji: the regional implications." The Contemporary Pacific (1990): 37-58.

Al-Rodhan, Khalid R. "A critique of the China threat theory: A systematic analysis." Asian Perspective (2007): 41-66.

Ayoob, Mohammed. "From regional system to regional society: Exploring key variables in the construction of regional order." Australian Journal of International Affairs 53, no. 3 (1999): 247-260.

Ayson, Robert. "Choosing Ahead of Time?: Australia, New Zealand and the US-China Contest in Asia." Contemporary Southeast Asia: A Journal of International and Strategic Affairs 34, no. 3 (2012): 338-364. 
Bainimarama, Voreque. "Hon Bainimarama address to the UNGA." Address, 71st Session of the United Nations General Assembly, New York, September 21, 2016. Accessed June 10, 2017. http://www.fiji.gov.fj/Media-Center/Speeches/HON-PM-BAINIMARAMA--ADDRESS-TO-THE71ST-SESSION-OF.aspx.

Biddick, Thomas V. "Diplomatic rivalry in the South Pacific: the PRC and Taiwan." Asian Survey 29, no. 8 (1989): 800-815.

Brady, Anne-Marie. "New Zealand-China relations: Common points and differences." (2008).

Broomfield, Emma V. "Perceptions of danger: The China threat theory." Journal of Contemporary China 12, no. 35 (2003): 265-284.

Brown, Peter. "Australian influence in the South Pacific." Australian Defence Force Journal 189 (2012): 66 .

Bull, Hedley. The Anarchical society. 4th ed. London: Palgrave McMillan, 2012.

Burges, Sean W. "Without sticks or carrots: Brazilian leadership in South America during the Cardoso Era, 1992-2003." Bulletin of Latin American Research 25, no. 1 (2006): 23-42.

Buzan, Barry . "The primary institutions of international society." In From International to World Society?, 161-204. Cambridge: Cambridge University Press, 2012.

Cantori, Louis J., and Steven L. Spiegel. "The international relations of regions." Polity 2, no. 4 (1970): $397-425$.

Cava, Litia. "PIDF Welcomes New Members." Fiji Sun. February 9, 2016. Accessed October 05, 2017. http://fijisun.com.fj/2016/02/09/pidf-welcomes-new-members/.

Dobell, Graeme. "Australia, Fiji and Pacific regionalism." APSI Strategist. November 24, 2014. Accessed July 20, 2017. https://www.aspistrategist.org.au/australia-fiji-and-pacific-regionalism/.

Dobell, Graeme. China and Taiwan in the South Pacific: Diplomatic chess versus Pacific political rugby. Sydney: Lowy Institute for International Policy, 2007.

Falk, Richard. "World orders, old and new." Current History 98 (1999): 29.

Firth, Stewart. "A reflection on South Pacific regional security, mid-2000 to mid-2001." (2001): 277283.

Firth, Stewart. Intervention and State-building in the Pacific: The Legitimacy of'co-operative Intervention'. Manchester: Manchester University Press, 2008. 
"Forum Communique - Fourty Seventh Pacific Island Forum." Pacific Islands Forum. September 10, 2016. Accessed November 17, 2017.

http://www.forumsec.org/resources/uploads/embeds/file/2016_Forum_Communique_11sept(1).pdf.

Fraenkel, Jon. "The Remorseless Power of Incumbency in Fiji’s September 2014 Election." The Round Table 104, no. 2 (2015): 151-164.

Fry, Greg, and Sandra Tarte. The new Pacific diplomacy. ANU Press, 2016.

Fry, Greg. "Framing the Islands: Knowledge and Power in Changing Australian Images of" the South Pacific"." The Contemporary Pacific (1997): 305-344.

Fry, Greg. "Politics of Regional Cooperation." In The South Pacific: Problems, Issues and Prospects, 169-81. Palgrave McMillan, 1991.

Fry, Greg. "Regionalism and International Politics of the South Pacific." Pacific Affairs 54, no. 3 (1981): 455-84.

Gopal, Avinesh. "Palau joins PIDF." Fiji Times. November 17, 2017. Accessed November 17, 2017. http://www.fijitimes.com/story.aspx?id=424171.

Gulliver, Aimee. "Gerry Brownlee meeting military leaders in China." Stuff. September 27, 2015. Accessed August 02, 2017. http://www.stuff.co.nz/national/politics/72454358/gerry-brownleemeeting-military-leaders-in-china.

Hameiri, Shahar. "China's 'charm offensive in the Pacific and Australia's regional order." The Pacific Review 28, no. 5 (2015): 631-654.

Hanson, Fergus. "The dragon in the Pacific: more opportunity than threat." (2008).

Hayward-Jones, J., and T. Newton Cain. "Pacific Island Leadership: PNG steps up." The Interpreter. Available at: www. lowyinterpreter. org/post/2014/08/28/Pacific-Island-leadership-PNG-steps-up. $\operatorname{aspx}(2014)$.

Hayward-Jones, Jenny. Big enough for all of us: Geo-strategic competition in the Pacific Islands. Sydney: Lowy Institute for International Policy, 2013.

Herr, Richard Allen, and Anthony Bergin. "Our near abroad, Australia and Pacific Islands regionalism." (2011).

Herr, Richard. "The Geopolitics of Pacific Islands' Regionalism: From Strategic Denial to the Pacific Plan." Fijian Studies: A Journal of Contemporary Fiji 4, no. 2 (2006): 111-125.

Hurrell, Andrew. "Brazil as a regional great power: a study in ambivalence." In Regional great powers in international politics, pp. 16-48. Palgrave Macmillan UK, 1992. 
Hurrell, Andrew. "Brazil as a regional great power: a study in ambivalence." In Regional great powers in international politics, pp. 16-48. Palgrave Macmillan UK, 1992.

Hurrell, Andrew. "One world? Many worlds? The place of regions in the study of international society." International Affairs 83, no. 1 (2007): 127-146.

Hussein, Bernadette. "The Big Retreat." Pacific Islands Monthly, November 1997, 11.

Ikenberry, G. John. "Illusions of empire: defining the new American order." (2004): 144-154.

Ikenberry, G. John. "Power and liberal order: America's postwar world order in transition." International Relations of the Asia-Pacific 5, no. 2 (2005): 133-152.

Ikenberry, G. John. Liberal Leviathan: The origins, crisis, and transformation of the American world order. Princeton University Press, 2012.

Kissinger, Henry. (2014). World Order. Penguin.

Kissinger, Henry. A world restored: Metternich, Castlereagh, and the problems of peace, 1812-22. Pickle Partners Publishing, 2017.

Kissinger, Henry. Diplomacy. Simon and Schuster, 1994.

Lawson, Stephanie. "The military versus democracy in Fiji: Problems for contemporary political development." The military and democracy in Asia and the Pacific (2004): 131-147.

Lal, Brij. Fiji: Fishing in Troubled Waters. Security Challenges 8, no. 4 (2012): 85-91.

Lum, Thomas, and Bruce Vaughn. "The Southwest Pacific: US interests and China's growing influence." China-US Economic and Geopolitical Relations (2007).

Mara, Ratu. "Keynote Address on the Occasion of the 30th Anniversary of the South Pacific Forum of Leaders 2001." Speech, Nauru, Yaren, August 17, 2001. Accessed April 8, 2017. http://www.pireport.org/articles/2001/08/17/keynote-address-he-rt-hon-ratu-sir-kamisesemara.

Martin, Lisa. "Fiji PM blames Australia, NZ for forum boycott." Stuff. September 9, 2015. Accessed May 02, 2017. http://www.stuff.co.nz/world/south-pacific/71908160/fiji-pm-blames-australianz-for-forum-boycott.

Mearsheimer, John J. "China's unpeaceful rise." Current History - New York. 690 (2006): 160.

Mearsheimer, John J. "The false promise of international institutions." International security 19, no. 3 (1994): 5-49.

Mearsheimer, John J. "The future of the American pacifier." Foreign Affairs (2001): 46-61. 
Mearsheimer, John J. The tragedy of great power politics. WW Norton \& Company, 2001.

Medcalf, R. "Australia-China defence ties: Beyond the hype. The Interpreter. Retrieved March 8, 2017." (2011).

Murphy, Tim. "Why China is splashing cash around in the Pacific." Newsroom. May 22, 2017.

Accessed August 02, 2017. https://www.newsroom.co.nz/2017/05/15/23681/chinese-money-ischanging-the-face-of-the-south-pacific.

Nadi, Samisoni Pareti in. "Fiji's push for alternative Pacific Islands Forum." ABC News. August 06, 2013. Accessed May 29, 2017. http://www.abc.net.au/news/2013-08-06/fiji-forum/4867748.

Nye, Joseph S., ed. International regionalism: readings. Little, Brown, 1968.

Patrick, Stewart. "World Order: What, Exactly, are the Rules?." The Washington Quarterly 39, no. 1 (2016): 7-27.

Pereira, Jorge F. Garzón. "Hierarchical regional orders: An analytical framework." Journal of Policy Modeling 36 (2014): 26-46.

Powles, A., and J. Souza-Santos. "Principled Engagement: Re-building Defence Ties with Fiji." Lowy Institute Analyses Paper 21 (2016).

Powles, Anna. "Finding Common Ground: New Zealand and Regional Security Cooperation in the Pacific." Regionalism, Security and Cooperation in Oceania. (2015): 81.

Ratuva, Steven. "A New Regional Cold War? American and Chinese Posturing in the Pacific." Asia \& the Pacific Policy Studies1, no. 2 (2014): 409-422.

Roberts, Susan M., Sarah Wright, and Phillip O’Neill. "Good governance in the Pacific? Ambivalence and possibility." Geoforum 38, no. 5 (2007): 967-984.

Schweller, Randall L., and Xiaoyu Pu. "After unipolarity: China's visions of international order in an era of US decline." International Security 36, no. 1 (2011): 41-72.

Shibuya, Eric. "The problems and potential of the Pacific Islands forum." The Asia-Pacific: A region in transition (2004): 102-115.

Slaughter, Anne-Marie. "International relations, principal theories." Max Planck encyclopedia of public international Law 129 (2011).

Smyth, Rosaleen, Nii-K. Plange, and Neil Burdess. "Big brother? Australia's image in the south pacific." Australian Journal of International Affairs 51, no. 1 (1997): 37-52. 
Solingen, Etel. Regional orders at century's dawn: Global and domestic influences on grand strategy. Princeton University Press, 1998.

Tarte, Sandra. "A New Pacific Regional Voice? The Pacific Islands Development Forum1." DIPLOMACY (2015): 79.

Tarte, Sandra. "Fiji's Look North Strategy and the role of China." In China in Oceania: Reshaping the Pacific? 2010, 118-131.

Tarte, Sandra. "New regional Pacific voice? An observer's perspective on the Pacific Islands Development Forum (PIDF), inaugural summit, Denarau, Fiji, 5-7 August 2013." (2013).

Tarte, Sandra. "Regionalism and changing regional order in the Pacific Islands." Asia \& the Pacific Policy Studies 1, no. 2 (2014): 312-324.

Tarte, Sandra. "Regionalism and globalism in the South Pacific." Development and Change 20, no. 2 (1989): 181-201.

Tavola, Kaliopate. "Re-thinking Pacific regional architecture whilst framing regional security." (2016).

Thakur, Ramesh. "Creation of the Nuclear-Free New Zealand Myth: Brinkmanship without a Brink." Asian Survey 29, no. 10 (1989): 919-939.

Tong, Anote, "Keynote Address at the Launch of the Pacific International Relations Forum". 9 October, Suva, October 2012. Accessed July 04 2017. <http://pidp.eastwestcenter.org/pireport/2012/October/1011-sp.htm>.

Tow, William T. "The ANZUS dispute: testing US extended deterrence in alliance politics." Political Science Quarterly 104, no. 1 (1989): 117-149.

Triska, Jan F. Dominant powers and subordinate states: the United States in Latin America and the Soviet Union in Eastern Europe. Duke University Press Books, 1986.

Tzu, Sun. The art of war. Shambhala Publications, 2005.

Walt, Stephen M. "Keeping the World Off Balance: Self Restraint and US Foreign Policy." (2000).

Weiss, Thomas G. "Rising Powers, Global Governance, and the United Nations." Rising Powers Quarterly 1, no. 2 (2016): 7-19.

Weiss, Thomas G. "The illusion of UN Security Council reform." Washington Quarterly 26, no. 4 (2003): 147-161.

Wesley-Smith, Terence. "China's rise in Oceania: Issues and perspectives." Pacific Affairs 86, no. 2 (2013): 351-372. 
Wesley-Smith, Terence. "Geopolitics, Self-Determination, and China's Rise in Oceania." In Selfdeterminable Development of Small Islands, pp. 85-99. Springer Singapore, 2016.

White, Hugh. "The limits to optimism: Australia and the rise of China." Australian Journal of International Affairs 59, no. 4 (2005): 469-480.

Windybank, Susan. "The China syndrome [China's growing presence in the Southwest Pacific.]." Policy: A Journal of Public Policy and Ideas 21, no. 2 (2005): 28.

Yang, Jian. "China in Fiji: displacing traditional players?." Australian Journal of International Affairs 65, no. 3 (2011): 305-321.

Zhang, Yongjin. "China and the emerging regional order in the South Pacific." Australian Journal of International Affairs 61, no. 3 (2007): 367-381. 